Revista Herencia Vol. 27 (1 y 2), 127-166, 2014

Recibido 12-02-2014 Aprobado 15-05-2014

\title{
"LOS VECINOS ACUDIERON PRESUROSOS Y DESPLEGARON ADMIRABLE ACTIVIDAD, RAYANA EN HEROÍSMO": Incendio y reedificación del templo parroquial de San Juan de Tibás
}

\author{
-A don Fabio Rojas Rodríguez, que siempre mantuvo vivo el sentimiento \\ de pertenencia e identidad con su terruño. Tibaseño que antiguamente \\ habitó el pueblo, posteriormente la ciudad y hoy el cielo eterno-.
}

Jafeth Campos

Ramírez. Historiador y Archivista, funcionario de la Dirección General del Archivo Nacional de Costa Rica y de la Universidad Estatal a Distancia. jafethcr34@gmail.com

\section{RESUMEN}

Destacando la tragedia del incendio de su templo parroquial, ocurrido a finales de ese siglo, este artículo analiza la evolución eclesiástica experimentada por el pueblo de San Juan en el siglo XIX. La reconstrucción representó una oportunidad para demostrar la valentía y la solidaridad de los sanjuaneños, así como la colaboración y la generosa amistad de pueblos vecinos. Además, la reedificación nutrió y reprodujo la sociabilidad, la cotidianidad y las estructuras comunales; en definitiva, fortaleció y recreó el sentir de la identidad sanjuaneña. Por último, también fomentó valores que siguen siendo muy necesarios en la sociedad costarricense y preparó el camino para la lucha por la cañería y el cantonato a partir de 1914.

Palabras claves: incendio, reconstrucción, templo parroquial de San Juan de Tibás, cotidianidad, identidad local, sociabilidad.

\section{Abstract}

This article analyzes the ecclesiastical evolution of San Juan during the nineteenth century, emphasizing the tragic fire that burned down its parish church at the end of that century. Rebuilding the church represented a chance to prove the sanjuaneño's bravery and solidarity, as well as the neighboring town's spirit of collaboration and generous friendship. Additionally, the process of reconstruction nurtured and reproduced San Juan's sociability, everyday life, and its communal structures, thus strengthening and recreating the sanjuaneño's identity. Finally, it also promoted values that are still much needed in Costa Rican society today, and prepared the road for the ensuing struggles to obtain an aqueduct and the status of canton starting in 1914.

Keywords: fire, reconstruction, parish of San Juan de Tibás church, everyday life, sociability, local identity. 


\section{Introducción}

Reunir o aglutinar a una comunidad alrededor de un santo o de una devoción ha sido trascendental en el origen y desarrollo de los pueblos. Ello fortalece el sentido de pertenencia; es decir, promueve una comunidad con identidad diferente de los otros pueblos y por lo tanto propia.

El desarrollo y la evolución eclesiástica que en el siglo XIX experimentaron los sanjuaneños, hasta la creación de la parroquia en 1865, incidió en el proceso de formación de la identidad local, comunal y pueblerina de San Juan. Esta identidad sirvió de basamento para afrontar y conllevar la tragedia comunal que representó el incendio del templo parroquial de San Juan de Tibás a finales del siglo XIX.

La reconstrucción del templo dejó de simbolizar un simple hecho material para pasar a representar el mejor momento de poner a prueba la solidaridad, la voluntad y la fraternidad de los sanjuaneños; así como la colaboración y la generosa amistad de pueblos vecinos, valores tan lejanos en la Costa Rica actual.

Además, la reedificación recreó, vigorizó, nutrió y reprodujo la cotidianidad, la sociabilidad, las estructuras comunales y la identidad pueblerina sanjuaneña, y esto abonó el terreno para que los sanjuaneños enfrentaran la siguiente lucha comunal: la cañería y cantonato, a partir de 1914.

A finales del siglo XIX, los sanjuaneños reconstruyeron su templo; por lo que es evidente que los infortunios y las desventuras no desaniman, sino que más bien alientan y comprometen a redoblar esfuerzos. Que la experiencia de hace más de un siglo sirva de aliento y apoyo a los sanjuaneños que hoy restauran su templo parroquial.

\section{Antecedentes eclesiásticos: de ermita a parroquia}

\section{La primera ermita: Ayuda de Parroquia}

El 8 de junio de 1834, el vecindario de El Murciélago solicitó al Jefe de Estado el permiso respectivo para construir una ermita en el llano llamado "El Murciélago"; es decir, San Juan de Tibás, actualmente.

Argumentaban a favor de su empresa que el cura de la parroquia de San José, a la cual pertenecían eclesiásticamente, había dado su asentimiento y la suma de quinientos pesos para contribuir a edificar lo que en aquella época se llamaba "Ermita Ayuda de Parroquia"; a estos quinientos pesos se les agregó lo recolectado por medio de una suscripción voluntaria entre los vecinos.

Además, hicieron ver la gran población que daría vida a la nueva ermita, pues expresaron que en ese vecindario había más de dos mil casas, y que, inmediatas al lugar donde la ermita debía construirse existían doscientas cincuenta y cinco casas, lo que ofrecía, finalmente, terreno para ubicarla y construirla ${ }^{1}$.

La suscripción voluntaria hecha entre los pobladores del vecindario de El Murciélago ascendió a la suma total de mil trescientos catorce pesos. Los contribuyentes, así como su valiosísimo aporte, pueden observarse en el Cuadro No. 1. El Ejecutivo, apoyando la solicitud, informó al Congreso y, el 14 de junio de 1834, este último poder concedió el permiso de la siguiente manera: "Se concede licencia al vecindario del Murciélago, barrio perteneciente a la Iglesia Parroquial de la ciudad de San José, para que construya una ermita ayuda de parroquia en el llano nombrado Murciélago". 


\section{Cuadro 1}

Suscripción voluntaria hecha entre los pobladores del vecindario de El Murciélago para construir la ermita

(8 De Junio De 1834) -en pesos y reales-

\begin{tabular}{|c|c|}
\hline Nombre & Contribución \\
\hline José María Esquivel (1) & 500 \\
\hline Cecilio Umaña (2) & 25 \\
\hline Félix Hidalgo (2) & 100 \\
\hline Pedro Vargas & 15 \\
\hline Rudecindo Rodríguez & 25 \\
\hline Judas Corrales & 5 \\
\hline Liberato Salazar & 25 \\
\hline Calixto Quirós & 30 \\
\hline Cornelio Quirós & 10 \\
\hline Miguel Salazar & 10 \\
\hline Antonio Salazar & 20 \\
\hline Casimiro Rojas & 40 \\
\hline Ignacio Rodríguez & 5 \\
\hline Segundo Soto & 5 \\
\hline Casimiro Soto & 5 \\
\hline José Francisco Jiménez & 20 \\
\hline Mateo Segura & 2 \\
\hline Augusto Quirós & 10 \\
\hline Trinidad Castro & 25 \\
\hline Francisco Chacón & 10 \\
\hline Calixto Castro & 10 \\
\hline Santiago Campos & 30 \\
\hline
\end{tabular}




\begin{tabular}{|c|c|}
\hline Nombre & Contribución \\
\hline Manuel Durán & 3 \\
\hline Manuel Rodríguez & 4 \\
\hline Eufrasio Rodríguez & 25 \\
\hline Silvestre Salazar & 20 \\
\hline José Alpízar & 5 \\
\hline Hermenegildo Soto & 15 \\
\hline Ramón Saborío & 10 \\
\hline Pedro Nolasco Jiménez & 2 \\
\hline Félix Alpízar & 5 \\
\hline Ascención Quirós & 5 \\
\hline José María Barrantes & 0,6 \\
\hline Manuel Monestel & 1 \\
\hline Ramón Salazar & 10 \\
\hline Eusebio Molina & 3 \\
\hline Valentín Molina & 10 \\
\hline Pedro Rivera & 10 \\
\hline Félix Rojas & 10 \\
\hline Cayetano Leitón & 5 \\
\hline José Trinidad Durán & 2 \\
\hline José Rodríguez & 20 \\
\hline Manuel Rodríguez Chaves & 10 \\
\hline Norberto Valverde & 10 \\
\hline Ignacio Esquivel & 1 \\
\hline Eusebio Rodríguez & 20 \\
\hline Ramón Vargas & 3 \\
\hline
\end{tabular}




\begin{tabular}{|c|c|}
\hline Nombre & Contribución \\
\hline José Antonio Rojas & 1 \\
\hline Juan de Jesús Jiménez & 2 \\
\hline Juan M. Soto & 4 \\
\hline Juan de la Cruz Rodríguez & 3 \\
\hline José de Jesús Rodríguez & 10 \\
\hline Juan Villalobos & 0,4 \\
\hline Martín Marín & 4 \\
\hline Segundo Campos & 1 \\
\hline Francisco Estrada & 1 \\
\hline Juan José Salazar & 0,4 \\
\hline Eusebio Barrientos & 5 \\
\hline Basilio Jiménez & 1 \\
\hline Joaquín Segura & 1 \\
\hline Hipólito Alfaro & 1 \\
\hline Sabina Gamboa & 1 \\
\hline Manuel Villalobos & 1 \\
\hline Felipa Barrientos & 2 \\
\hline Josefa de Jesús Cerdas & 0,4 \\
\hline José María Villalobos & 3 \\
\hline José Zumbado & 1 \\
\hline Fermín Mondragón & 0,6 \\
\hline Francisco Álvarez & 2 \\
\hline Antolino Chacón & 2 \\
\hline José de Jesús Herrera & 2 \\
\hline Ambrosio Alvarado & 1 \\
\hline
\end{tabular}




\begin{tabular}{|c|c|}
\hline Nombre & Contribución \\
\hline María Zamora & 1 \\
\hline Manuel Mora & 0,4 \\
\hline Ramón Cervantes & 0.4 \\
\hline Carmen María Segura & 1,4 \\
\hline Manuel Barrientos & 2 \\
\hline Encarnación Chaves & 2 \\
\hline Jesús Monestel & 1 \\
\hline Norberto Masís & 1,4 \\
\hline Manuel Segura & 1,4 \\
\hline León Torres & 2 \\
\hline Josefa Umaña & 0,2 \\
\hline María Rojas & 1 \\
\hline Nicolás Solís & 1 \\
\hline José Quirós & 1 \\
\hline José Trinidad Salazar & 4 \\
\hline Cecilio Chaves & 1,4 \\
\hline Manuel Chacón & 0,6 \\
\hline Simona Castro & 10 \\
\hline Juan Rodríguez & 2 \\
\hline Domingo Barrientos & 4 \\
\hline Toribio Umaña & 1 \\
\hline Mariano Rodríguez & 10 \\
\hline Santiago Lobo & 0,4 \\
\hline Félix Estrada & 0,4 \\
\hline Francisco Marín & 1 \\
\hline
\end{tabular}




\begin{tabular}{|c|c|}
\hline Nombre & Contribución \\
\hline Cayetano Rojas & 1 \\
\hline Fidel Gamboa & 2 \\
\hline Higinio Herrera & 0,4 \\
\hline José Monge & 0,4 \\
\hline José M. Guzmán & 5 \\
\hline Juan Araya & 4 \\
\hline Marcelo Bautista & 0,4 \\
\hline Hilario Villarreal & 5 \\
\hline Manuel Fernández & 0,4 \\
\hline Marcelina Solera & 1 \\
\hline Trinidad Quirós & 2 \\
\hline José María Vargas & 2 \\
\hline TOTAL & $1314(3)$ \\
\hline \multicolumn{2}{|c|}{$\begin{array}{l}\text { (1) Cura Párroco de la iglesia de la ciudad de San José, que apoyó en todo momento la edificación de la ermita. } \\
\text { (2) Sacerdote. } \\
\text { (3) Según las cuentas del documento original, el total de la contribución fue } 1304,2 \text {; no obstante, el contador sumó mal y } \\
\text { erró 9,6; por lo tanto, el total fue de } 1314 \text {. Además, Joaquín B. Calvo ofreció } 4 \text { pesos y Rafael Gallegos, } 40 \text { fanegas de cal. }\end{array}$} \\
\hline
\end{tabular}

Según se desprende de los documentos, para mediados de 1837 la ermita ya estaba en funcionamiento y faltaba solamente el acabado de algunos detalles menores.

El vecindario de El Murciélago fue una extensa e importante región de San José, ubicada al norte y noreste de la ciudad capital, y comprendía los cantones actuales de Vázquez de Coronado, Moravia, Goicoechea, Tibás, y el distrito josefino de La Uruca; es decir, aproximadamente todo el territorio entre el río Torres al sur y el río Virilla al norte.

La primera ermita construida en el extenso vecindario de El Murciélago, estuvo ubicada en San Juan (Llano o Sabana de El Murciélago). Desde 1837 dicha ermita congregaba a todo el vecindario de El Murciélago ${ }^{3}$.

Una vez que la ermita estuvo modestamente construida para congregar al vecindario - para que este, en forma pública y masiva, tributara cómodamente su culto al Ser Supremo-, en 1837 se estableció la "ayuda de parroquia de San 
Juan", perteneciente a la parroquia matriz de San José. Dicha ayuda de parroquia estuvo compuesta prácticamente por todos los barrios que integraron el vecindario de El Murciélago, a saber: San Juan, San Pedro, San Gabriel, Uruca, San Vicente y San Isidro ${ }^{4}$.

\section{Intento fallido: separación de la ayuda de parroquía}

La nueva categoría eclesiástica fortaleció el sentido de pertenencia, a tal grado que, en julio de 1838, los señores Ascensión Quirós, Timoteo Huertas, Rafael Marín y Mariano Rojas -apoderados, el primero de los barrios de San Juan y San Pedro, el segundo de San Vicente y San Isidro, y los dos restantes de los barrios de San Gabriel y Uruca respectivamente-dieron poder a Juan Esquivel para que pidiera y lograra la separación eclesiástica de esta ayuda de parroquia de la iglesia matriz de San José, según la división realizada por el cura de dicha ciudad, Juan de los Santos Madriz.

Entre los considerandos que motivaron a los murcielagueños a solicitar la separación se menciona la finalización del templo con todos sus ornamentos religiosos necesarios, la producción de suficientes proventos o rentas para la subsistencia de un sacerdote y la cantidad existente a la fecha (julio de 1838) de aproximadamente cuatro mil personas en el vecindario de El Murciélago. Por esto, era necesario e imperioso contar en dicho vecindario y ermita con un sacerdote que administrara el "pasto espiritual" y guiara al rebaño ${ }^{5}$.

Este dato reafirma la certeza de que el templo ya estaba concluido y también la vigorosidad demográfica y económica de El Murciélago. Aunque no hay más información al respecto, todo indica que el resultado de la empresa fue negativo.

\section{Se establece la parroquia en San Juan}

El 27 de febrero de 1852, los vecinos del distrito de San Juan del Murciélago solicitaron al obispo la independencia religiosa, por medio del establecimiento de la parroquia.

Entre las razones favorables para erigir dicha parroquia, los sanjuaneños esgrimieron que el templo construido en 1834, con la colaboración de todo el vecindario, se conservaba aún y que se había mejorado notablemente; además, que el distrito contaba con un importante número de habitantes ${ }^{6}$. Sin embargo, las autoridades religiosas no apoyaron la solicitud debido a asuntos e intereses económicos.

El 17 de setiembre de 1864 los sanjuaneños pidieron elevar la filial de San Juan a la categoría de parroquia, con lo cual, en esta ocasión, recibieron una respuesta favorable.

Alegaron, además, que poseían templo bastante "capaz y decente" y que en ese momento estaba por concluirse un panteón "cerrado de paredes de cal y canto"7, todo lo cual demostraba que los vecinos aspiraban a mejorar espiritualmente y por ello consideraban ser merecedores del título de parroquia.

Las autoridades respectivas iniciaron una serie de diligencias para decidir sobre el caso y los sanjuaneños nombraron al señor Joaquín Salazar como representante.

En dichas diligencias, los interesados volvieron a mencionar los factores que hacían propicio el establecimiento de la parroquia: una población adecuada en el barrio de entre cincuenta a cien familias, condiciones económicas necesarias 
para sostener al cura párroco, ornamentos religiosos, disposición de los vecinos a suplir todo lo indispensable para el servicio y culto parroquial, además de que la elevación a parroquia favorecería el culto divino en el barrio de San Juan .

Finalmente, el obispo de Llorente, el 2 de enero de 1865, erigió la parroquia de San Juan Bautista. Interinamente, fue nombrado el presbítero Pablo Montero como "teniente cura" de la nueva parroquia.

Reunir o aglutinar a una comunidad alrededor de un santo o de una devoción ha sido de trascendental importancia en el origen y desarrollo de los pueblos, porque compartir cotidianamente una fe hace que los lazos de unión entre los vecinos se fortalezcan y crezca el sentimiento de pertenencia y de identidad de todos bajo un mismo santo que se convierte en algo propio y representativo del lugar y la comunidad. Ello origina, desarrolla y fortalece el sentido de lugar de los pobladores, pues los hace sentirse comunidad con identidad diferente de los otros pueblos y por lo tanto propia, lo cual es también una necesidad particular de la identidad de los pueblos.

Definitivamente, todo el proceso que enfrentaron los sanjuaneños, desde la construcción de la ermita en 1834, pasando por el establecimiento de la ayuda de parroquia en 1837, hasta la creación de la parroquia (1865), incidió en el proceso de formación de la identidad local, comunal y pueblerina de San Juan, hecho que les permitió luego afrontar y conllevar cualquier adversidad o tragedia comunal; tal es el caso del incendio que padeció el templo parroquial de San Juan de Tibás a finales del siglo XIX.

\section{El incendio del templo parroquial de San Juan}

No se puede evocar el incendio que sufrió el templo parroquial de San Juan de Tibás sin recurrir al contexto histórico-eclesiástico, pues es dentro de este como se ha forjado la identidad sanjuaneña. Además, es este contexto e identidad lo que va a permitir enfrentar y superar la tragedia comunal vivida por los sanjuaneños a finales de siglo XIX.

El incendio del templo parroquial de San Juan ocurrió el 26 de setiembre de 1897 y representó un evento que impactó fuertemente la vida pueblerina de los sanjuaneños. De igual forma, representó una oportunidad para poner a prueba la identidad y demostrar el coraje, la valentía y generosidad del pueblo, así como la grata amistad de pueblos vecinos.

Los principales testimonios sobre el incendio los ofrecen los periódicos de la época, los cuales narran que fue en horas de la madrugada del día señalado cuando se dio la voz de alerta:

Sería cosa de las 3 de la mañana cuando Juan Rojas, vecino de San Juan, que ocupa una casa tras los muros posteriores de la iglesia, se despertó oyendo un horrible traquido, al mismo tiempo que una ola sangrienta penetró por la ventana e inundó la habitación: era el reflejo rojizo del colosal incendio. En cuanto al ruido que lo despertó fue el estallar de la ventana redonda que se hallaba sobre el altar mayor. Levantóse precipitado y fue a despertar al señor cura y al sacristán. El cura quiso entrar a la iglesia pero ya era tarde, todo ardía... (Diario de Costa Rica,1897, s.p.).

El sacristán de la Iglesia de San Juan, que Rojas despertó ante la emergencia, era el señor Juan Jiménez Vega, quien ejerció tal cargo tanto antes como después del incendio. El cura de San Juan, Víctor de Gréve Plum, notable sacerdote del clero costarricense de esos años ${ }^{9}$, expresó su testimonio sobre el siniestro de la siguiente manera: 
En la madrugada del domingo 26 de septiembre - como a las tres y cuarto- oí fuertes golpes y gritos en la ventana. Creí que me llamaban para un enfermo. Me levanto, abro los postigos y veo salir de la ventana de la iglesia, que se halla frente a la casa cural, una llama inmensa, en cuyo medio diviso aún el esqueleto del órgano. Salgo corriendo con las Ilaves. En este brevísimo rato ya había llegado la llama al techo de la iglesia.

Mi primer pensamiento fue salvar las formas consagradas. Abro la sacristía, pero veo que era imposible entrar por aquel lado. No había escala en el altozano para penetrar por la ventana. Corrí a buscar quien me ayudara. No pudiendo llegar a los campanarios, - no se habían podido tocar tampoco las campanas-, que ya estaban ardiendo, un policía disparó cinco tiros de revólver. Los vecinos acudieron presurosos y desplegaron admirable actividad, rayana en heroísmo. Imposible era salvar el templo. Gracias a la presencia de espíritu y la activa energía no sólo de los hombres, sino también de las mujeres, se salvaron los armarios de la sacristía y se apartó el incendio de este lado y de los campanarios. Como a las cinco cayó la armazón del techo y las Ilamas desaparecieron. (El Mensajero del Clero, 1897, p. 169).

La parte de la estructura que más sufrió fue el techo, que fue fácil presa del fuego debido probablemente a que estaba construido en caña de carrizo con horcones de cedro. Sobrevivieron las paredes de calicanto de los costados norte, sur y este; de igual forma, la pared de la fachada. Sobre dichas paredes, que fueron muy bien edificadas y refaccionadas, se levantó el actual templo parroquial de San Juan de Tibás (Véase Fotografía No. 1). También sobrevivió la sacristía que no fue consumida por el voraz incendio.

Las pérdidas fueron muchas y cuantiosas, la mayoría irreparables. Entre los objetos deteriorados y/o quemados se citan el altar mayor y nueve altares laterales, el púlpito, dos confesionarios, aproximadamente cincuenta reclinatorios, los vasos sagrados,

Fotografía 1.

Incendio del Templo

Parroquial de San Juan de Tibás - setiembre de 1897

Fuente: "El Incendio de la Iglesia de San Juan. Datos Precisos",

Diario de Costa Rica

(San José), 28 de setiembre de 1897,

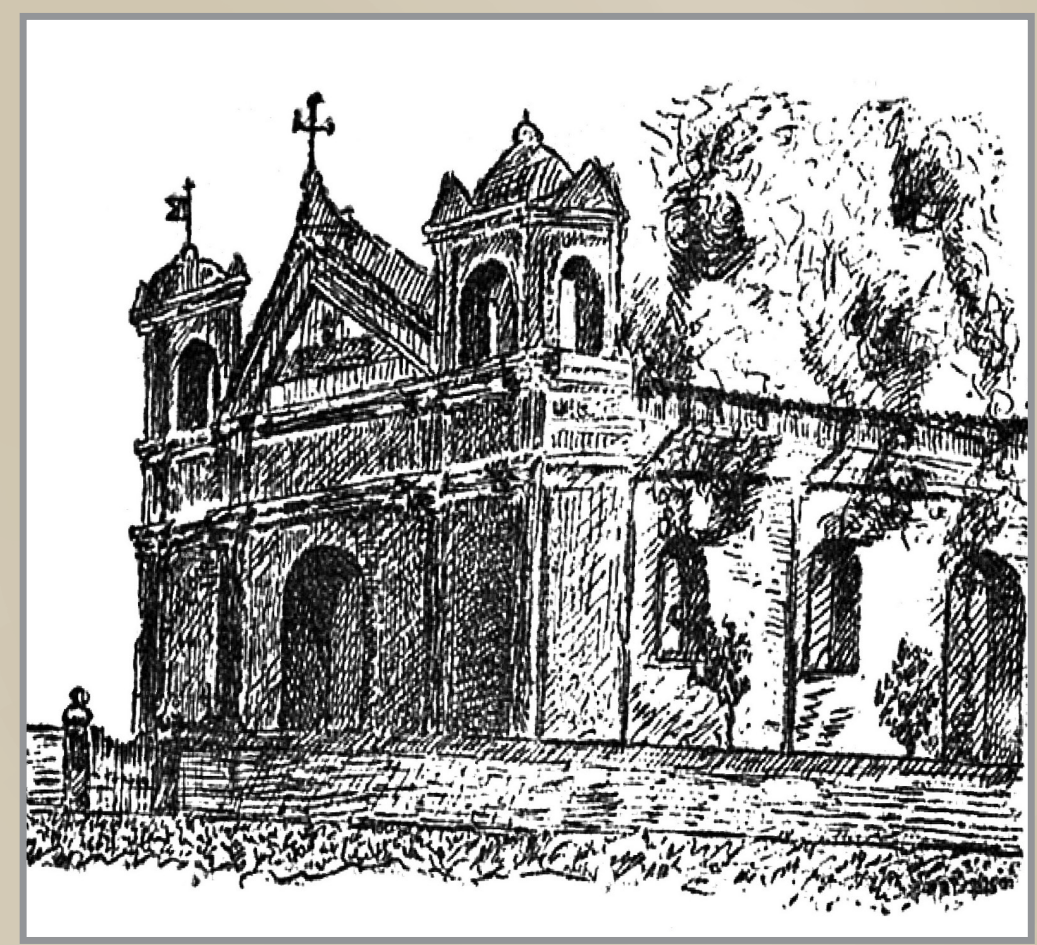


la pila bautismal, las imágenes - en total veinticuatro-incluida la del santo patrono San Juan -escultura hecha en Guatemala-, andas, candeleros y arañas. Además de las alfombras, en especial la "alfombra magnífica que cubría la delantera del altar mayor", las puertas y "el pavimento de ladrillos" (piso) recién colocado.

También, entre las pérdidas destaca el órgano que valía 15000 colones, importado recientemente bajo el celo de un notable artista, "hermoso aparato de construcción moderna y único de su clase que había en el país ¡Una verdadera gran pérdida!"; igualmente, una magnífica custodia de oro, obra de arte con valor de 2000 colones $^{10}$. En total las pérdidas económicas fueron valoradas en alrededor de más de 100000 pesos ${ }^{11}$.

A pesar del siniestro la iglesia continuó con sus actividades, el sacerdote Víctor de Gréve celebró misa a las ocho de la mañana del trágico domingo 26 de setiembre de 1897, posiblemente en la plaza de San Juan (actual parque) pues, según dicho sacerdote, el pueblo católico se veía "reducido a una pieza estrechísima y privados de casi toda comodidad para celebrar los oficios de culto"12.

\section{El incendifo del templo parroquial de San Juan: el origen}

El incendio comenzó en el presbiterio y las fuentes consultadas señalan que el siniestro pudo haber iniciado a las 21 horas (9 p.m.) del sábado 25 de setiembre de 1897, o a la 1 a. m. del siguiente día.

El origen del siniestro fue una lámpara ubicada en el altar, que cayó sobre una alfombra derramando el canfín y rápidamente las llamas alcanzaron las cortinas con que se adornaba el altar. Al respecto un periódico de la época (Diario de Costa Rica, 1897, s.p.) indicó:

El incendio según parece, comenzó por la lámpara del Santísimo, que se cayó y prendió fuego a una cortina, pues la iglesia estaba de gala con motivo de la fiesta de Nuestra Señora de Mercedes. Aquí nació el fuego que tomó cuerpo de una manera asombrosa, debido en parte a que el edificio se estaba pintando en estos días y el aceite y aguarrás favorecieron el fuego.

Del siniestro, fue culpado el sacristán Juan Jiménez Vega, pues según esta versión el sacristán fue quien dejó encendida la lámpara. También, las fuentes consultadas indican que Juan Jiménez Vega se alumbraba con una candela, la que puso sobre el altar olvidándola al salir, y esta se consumió traspasando el fuego al altar ${ }^{13}$.

En el expediente levantado por el Juzgado del Crimen de San José para averiguar si había existido complicidad en el incendio, el sacristán Jiménez Vega expresó en su declaración, ofrecida el 25 de octubre de 1897, lo siguiente:

Que la misma noche que ocurrió el incendio, hubo fiesta solemne en la Iglesia de San Juan y con ese motivo se iluminó el edificio. Que cuando terminó la función, el declarante apagó las luces, dejando dos encendidas como siempre se acostumbraba y en seguida se retiró. Que como a las tres de la mañana lo despertaron sus vecinos y habiéndose levantado el declarante se fue a la Iglesia y ya la encontró casi totalmente destruida por el fuego. Que el declarante cree que lo sucedido fue casual ${ }^{14}$.

Otra interpretación sobre el incendio es que fue provocado, con la intención de hurtar una magnífica custodia, pues esta nunca apareció entre los escombros del templo parroquial de San Juan. Muchos años después, se conoció la noticia que la mencionada custodia "había sido sacada" del país ${ }^{15}$. Esta custodia fue descrita como: 
Labrada en oro de 22 kilates y ornamentada con diamantes [...] de incalculable valor. Tanto, efectivamente, valía esa custodia que, para seguridad de la misma, más de una vez la Curia de San José intentó trasladarla a la Catedral a lo que siempre se opusieron [sic] los sanjuaneños.

El caso en verdad rarísimo de que después del incendio no se encontrara entre las ruinas, el menor vestigio de esa valiosísima custodia, que era tan grande como ninguna otra se ha visto en Costa Rica, dio origen a la sospecha de que el incendio del templo fuera provocado por ladrones, que habiendo robado tantos y tan valiosos objetos, diéronle fuego para no dejar rastro del sacrilegio hecho. Y todavía existe en el vecindario la impresión de esta sospecha. (La Tribuna, 1934, p. 12.).

Sin embargo, entre tantas versiones de lo sucedido en el templo parroquial de San Juan, es necesario reproducir la versión de uno de los más importantes testigos del siniestro, el Sacerdote de San Juan, Presbítero Víctor de Gréve Plum, quien escribió en el periódico El Mensajero del Clero (1897, p. 170) lo siguiente:

Sobre los orígenes del incendio oigo que algunos se complacen en conjeturas. No cabe aquí ninguna sospecha de crimen ni tampoco de descuido. El sacristán es persona de escrupulosa solicitud. En la noche del sábado se celebró solemne rosario; la iglesia estaba adornada para la función de Nuestra Señora de la Merced, que habíamos trasladado para el domingo 26. Quedaron encendidas dos lámparas de aceite, como siempre. Me parece sumamente improbable que haya quedado en el coro ó en las arañas otra luz. Creo que el incendio había empezado ya a las nueve de la noche. Antes de recogerme acostumbraba dar una vuelta por el exterior del templo. Lo hice el sábado. Noté por la ventana cierta claridad, pero no concebí ni sombra de sospecha de una desgracia. Suponía sencillamente que era la luz de la lámpara del Santísimo. Según los indicios que se me declararon, desde el momento que acudí a la iglesia debe de haber empezado el incendio en el presbiterio. Afirmar el cómo quedará imposible.

Como se mencionó párrafos atrás, el Juzgado del Crimen de San José desarrolló una sumaria para averiguar si había existido complicidad en el incendio del templo de San Juan. Dicho proceso judicial inició el 27 de setiembre de 1897 y finalizó el 10 de diciembre de ese mismo año.

En estas diligencias judiciales declararon el cura de San Juan, Víctor de Gréve Plum, el Agente de Policía de San Juan, Pánfilo Segura Jiménez y el ya mencionado sacristán de la iglesia, Juan Jiménez Vega. Los tres declarantes coincidieron en señalar que el incendio fue casual ${ }^{16}$. En razón de ello, se dictó auto de sobreseimiento.

\section{El incendio del templo parroquial de San Juan: la reedificación}

Luego de la misa celebrada a las ocho de la mañana del fatídico domingo 26 de setiembre de 1897, los vecinos - que desde la madrugada daban pruebas de heroísmo al enfrentarse al fuego que destruía el templo construido con gran sacrificio por sus antepasados-continuaron con el trabajo, apagando las cenizas y buscando objetos de valor entre los escombros. Así fueron encontrados íntegramente la concha bautismal y la cerradura del tabernáculo, entre otros objetos.

A medio día, el sacerdote Víctor de Gréve celebró reunión con los vecinos; luego, a la una y media de la tarde, llegaron al triste escenario el Obispo Bernardo 
Augusto Thiel Hoffman y otros clérigos. Los vecinos y algunos capitalinos que se encontraban en el distrito josefino de San Juan nombraron director honorario de la reedificación del templo al Obispo Thiel.

En la reunión celebrada entre el Presbítero de Gréve y los vecinos se acordó realizar una suscripción voluntaria con la finalidad de iniciar la tarea de reedificación. A las dos de la tarde del citado domingo 26, la subscripción rondaba los 27000 colones y tres días después, alcanzó la suma definitiva de entre 36000 a 38000 colones $^{17}$.

La reedificación del templo fue labor de la Junta Edificadora de la iglesia de San Juan. Las Juntas Edificadoras fueron organizaciones o estructuras propias y permanentes de la Iglesia Católica en todas las parroquias (equivalentes a lo que en la actualidad se conoce como Consejos Económicos). Su labor consistía en encargarse de la construcción y mantenimiento de los edificios eclesiásticos, los cuales podían ir desde un templo hasta salones parroquiales o de catequesis y casa cural. Por lo general, estaban conformadas por un presidente, un vicepresidente, un tesorero, un secretario, un ecónomo y vocales propietarios y suplentes.

La Junta Edificadora de San Juan que le correspondió reedificar el templo fue nombrada en mayo de 1897 y estuvo integrada por los siguientes señores: Víctor de Gréve Plum (presidente), Lino Vargas (vicepresidente), José Saborío (tesorero), Gerardo Valverde (secretario) y los vocales Salvador Rodríguez, Salustiano Soto y Santos Rojas ${ }^{18}$.

El cargo de ecónomo fue ejercido por José María Jiménez hasta el 16 de octubre de $1898^{19}$; lo sucedió Baltasar Valenciano desde el 16 de octubre de 1898 hasta el 12 de marzo de 1899; luego lo ejerció José Bolaños desde el 12 de marzo de 1899 hasta el 8 de julio de 1900 y, por último, Casimiro Marín, a partir del 8 de julio de $1900^{20}$.

Posterior al incendio, la primera sesión efectuada por la Junta Edificadora de la iglesia de San Juan aconteció el 24 de octubre de 189721. En la labor de reconstruir el templo, la Junta Edificadora no solamente se encargó de los aspectos meramente técnicos (materiales, contratación de carpinteros y albañiles, y otros) y de vigilar los trabajos, sino de gestionar, realizar y organizar todas aquellas actividades que generaran recursos económicos para invertirlos en la obra.

El esfuerzo realizado por la Junta Edificadora de la iglesia de San Juan fue titánico, pues cada uno de sus miembros se encargó de vigilar por días los trabajos de la reconstrucción. Así, el día lunes, el señor Salvador Rodríguez (vocal) fue el encargado de entenderse con la obra; el martes, Baltasar Valenciano; el miércoles, Salustiano Soto; el jueves, Lino Vargas; el viernes, José María Jiménez; y el sábado, el señor Santos Rojas ${ }^{22}$.

\section{Reedificación del templo parroquial de San Juan: actividades de financiamiento}

Una de las actividades de financiamiento más importante fue la suscripción voluntaria. Aparte de la suscripción anteriormente referida — con la cual se inició la tarea de reedificación - la Junta Edificadora, en sesión ordinaria celebrada el 9 de abril de 1899, tomó el acuerdo de realizar otra ${ }^{23}$. Como encargados de gestionarla y desarrollarla fueron designados los señores Lino Vargas y José Saborío, vicepresidente y tesorero, respectivamente, de la Junta Edificadora ${ }^{24}$.

Aunque se desconoce la cantidad de dinero aportado mediante la suscripción realizada en 1899, es necesario destacar la importancia de esta actividad, pues la suscripción voluntaria posibilitó la reedificación del templo, al permitir la participación de todo el pueblo sanjuaneño, desde el adinerado hasta el más humilde, además de personas amigas. 
Otra actividad que la Junta Edificadora efectuó para reedificar el templo fue un empréstito por la cantidad de 5000 colones. Este préstamo fue suscrito con un banco entre finales de 1898 y principios de 1899, y debía ser cancelado en un plazo de tres meses ${ }^{25}$.

Sin embargo, la situación económica de la Junta Edificadora era sumamente estrecha para cancelar el crédito en el lapso estipulado, por lo que en varias ocasiones, a lo largo de 1899, dicha junta negoció la ampliación del pago del préstamo ${ }^{26}$. En razón de lo anterior, todavía en enero de 1900 la Junta Edificadora de la iglesia de San Juan estaba abonando la deuda al banco ${ }^{27}$.

Otra estrategia utilizada por la Junta Edificadora para generar recursos fueron las rifas. Dicha Junta acordó, en sesión del 28 de mayo de 1899, realizarlas cada quince días ${ }^{28}$, contando, además, con la desinteresada colaboración de algunos sanjuaneños.

Estas rifas se celebraban un día y en un lugar específico, y para el orden y su buen desarrollo, los miembros de la Junta Edificadora colaboraban según horario previamente establecido.

Así, la primera rifa se llevó a cabo el 2 de julio de 1899 y de diez de la mañana a doce medio día colaboró don José Bolaños; de doce medio día a dos de la tarde, don Santos Rojas; de dos a cuatro de la tarde, el señor José Saborío; y don Lino Vargas, de cuatro de la tarde en adelante ${ }^{29}$. Además, fungieron como vigilantes: el presidente de la Junta Edificadora (presbítero Víctor de Gréve Plum) y los señores Baltasar Valenciano y Gerardo Valverde ${ }^{30}$.

\section{Turnos}

Los turnos representaron una de las actividades más importantes en el proceso de reedificación, no solamente por el dinero que generaban, sino por representar la mejor oportunidad para estrechar los lazos de unión y de amistad entre los sanjuaneños con otros pueblos vecinos. Simbolizaron un punto medular de alianza social y un bastión de la convivencia y de la identidad local. En este sentido, los turnos nutrían, recreaban, mantenían y reproducían la cotidianidad pueblerina, la sociabilidad y las estructuras comunales de San Juan.

En los turnos, los sanjuaneños compartían y dialogaban sobre sus preocupaciones y problemas cotidianos, sobre las inquietudes de su entorno y de su comunidad, así como de sus alegrías y tristezas.

Las primeras evidencias de los turnos destinados a contribuir a la reedificación del templo de San Juan se hallaron a finales de noviembre de 1897 cuando la Junta Edificadora, por medio de su presidente, le solicitó al Ministro de Gobernación el permiso respectivo para celebrar cuatro turnos ${ }^{31}$. De esta forma, a mediados de diciembre de 1897, el presidente de la República, Rafael Yglesias Castro (último Presidente del Siglo XIX y primero del Siglo XX), concedió el permiso a la Junta Edificadora de la iglesia de San Juan para celebrar tres turnos, efectuados en intervalos de tres meses y bajo la vigilancia de la autoridad política ${ }^{32}$.

El primer turno se efectuó el domingo 2 de febrero de 1898. Fue anunciado en el periódico El Eco Católico de Costa Rica del sábado 29 de enero de 1898, mediante una invitación que hizo la Junta Edificadora a los pueblos vecinos para que formaran parte y contribuyeran con donativos. Atendiendo la invitación, asistieron varios pueblos vecinos; sin embargo, es de destacar la participación del pueblo de San Isidro de San José. En este sentido, El Eco Católico de Costa Rica (1898, pp. 31-32) indicó que:

Si bien algunos caballeros de Santo Domingo y San Vicente concurrieron al acto, ninguno de estos pueblos mostró en tanto grado su espíritu de fraternidad como el de San Isidro de San José. 
A las 11 a.m. Ilegaron numerosos vecinos de este pueblo a San Juan, tanto a pié como a caballo, capitaneados por su entusiasta señor Cura, Presbítero don Ricardo Zúñiga. Divisados que fueron a lo lejos, fueron a recibirlos el Cura de San Juan, Presbítero doctor de Gréve, la Junta Edificadora y las autoridades; en el encuentro hubo resonantes jvivas! cohetes y música, compuesta de la filarmonía Isidreña y de la música preparada en San Juan.

En el atrio de la Iglesia dio el P. De Gréve, la bienvenida al pueblo de San Isidro en sentidas frases, bienvenida que contestó el P. Zúñiga con magnífico discurso que le mereció repetidos aplausos.

El pueblo de San Isidro de San José no solamente se desplazó hasta San Juan a apoyar con su presencia, sino que aportó algunos productos para ser vendidos y de esta manera contribuir con la reedificación del templo sanjuaneño:

Los vecinos de San Isidro traían además de su cuantioso óbolo pecuniario, como 35 carretas con leña para subastarlas y venderlas, todo lo cual hizo que el producto del Turno alcanzara a más de 2,000 pesos, cantidad considerable para un Turno celebrado en un pueblo pequeño. Reinó hasta el fin el orden más completo y la mayor animación. (ibíd, p. 32).

Definitivamente, el turno efectuado en San Juan el domingo 2 de febrero de 1898, generó algún dinero con la finalidad de reedificar el templo; pero también representó la ocasión para demostrar los nexos de unión y amistad entre sanjuaneños e isidreños. Sin duda alguna, los vecinos de San Juan quedaron sumamente agradecidos, pues en dicho periódico (Eco Católico) se lee lo siguiente:

Tiene de especial esta fiesta el haber sido una muestra de fraternidad, entre dos pueblos vecinos y clara prueba del espíritu progresista del pueblo isidreño, que no contento con dar vuelo al progreso en su mismo seno, acude a fomentarlo y ayudarlo en aquellas otras poblaciones hermanas que están animadas de las mismas intenciones. Muestra también de que no contentos con dar generosamente su óbolo para el culto en su hermoso templo, acuden a manifestar su desinterés y espíritu caritativo en los pueblos que imitan sus ejemplos. Nos olvidábamos de advertir que la señora isidreña doña Teodora Flores de Vargas, regaló una hermosa imagen de N. S. de Soledad.

¡Bien por el señor Cura de San Isidro que tan nobles sentimientos ha inculcado en aquella sociedad! ¡Felicitación al pueblo que así ha correspondido a su Cura!

Enhorabuena al pueblo sanjuaneño que cuenta con tan generosos amigos. (ibíd).

Definitivamente, el incendio del templo parroquial de San Juan dejó de ser un simple y llano hecho material - la reconstrucción como tal- para transformarse en muchos otros significados como la fraternidad, la solidaridad, la voluntad, el desinterés y el espíritu caritativo, la fe en la unión, los nobles sentimientos, el cariño, la colaboración y la generosa amistad entre los pueblos, valores tan lejanos en la Costa Rica actual.

A pesar de que el presidente de la República concedió permiso a la Junta Edificadora de la Iglesia de San Juan, para celebrar tres turnos (efectuados en intervalos de tres meses), las fuentes consultadas no reseñaron información sobre los otros dos turnos por efectuarse posiblemente en mayo y en agosto de $1898^{34}$. Es probable que estos dos turnos no se desarrollaran. 
No obstante, las fuentes consultadas indican la realización de otro turno al año siguiente, con la finalidad de contribuir con la reedificación del templo de San Juan. La organización de dicho turno y la escogencia del día por realizarse estuvo a cargo de la Junta Edificadora. Para ello se nombraron comisionados como sigue:

Para el Distrito Central a los señores don Jesús Murillo y don Fulgencio Montero. Para el Distrito de La Concepción a los señores don Jesús Alpízar y don Enrique Rojas. Para el Distrito de Mercedes a los señores don Santos Rojas y don Ramón Quirós Q. Y para el Distrito de Jesús a los señores don Concepción Rivera y don Juan Valverde ${ }^{35}$.

El turno se realizó el domingo 22 de enero de 1899 y sobre lo acontecido se expresó lo siguiente:

Sabido es que ese pueblo [San Juan] es uno de los más pequeños en extensión territorial y que no es tampoco de los que pudieran llamarse "pueblos ricos"; sin embargo, las gentes que lo forman destacan en primera línea, si el cómputo se hace por lo que toca a desinterés y generosidad. Muchos miles de pesos han erogado los vecinos para la construcción de su iglesia, ya en suscripciones, ya en donativos particulares $y$, sin embargo, el turno produjo 1.800 pesos y una rifa que se hizo el siguiente domingo, 306 pesos. Bien se colige que el pueblo de San Juan es pueblo de fe y de unión, que cuando se trata de edificar un templo del Señor, no repara en su pobreza para gastar su dinero con fuerza y buena voluntad. (El Eco Católico de Costa Rica, 1899, p. 24).

Después de contar con la aprobación del "Supremo Gobierno" para realizar nuevos turnos y ayudar de esta manera con la reconstrucción, los siguientes se verificaron el domingo 26 de febrero de 1899 y el domingo 30 de abril del mismo año ${ }^{36}$. Para efectuar el turno del 30 de abril, y ante la renuncia de los comisionados de los distritos Central y Mercedes, se nombraron como sustitutos a los señores Isidro Rodríguez y Esteban Araya, por el distrito Central; y a Patricio Arias y Eliseo Soto, por el de Mercedes ${ }^{37}$. También es necesario señalar que en la realización de los turnos el pueblo contribuía notablemente con donativos.

La Junta Edificadora acordó en octubre de 1899 celebrar turnos a partir del próximo diciembre, iniciando el domingo 3 y para ello la Junta convino invitar mediante "hojas sueltas" a los pueblos vecinos, por lo que se dispuso a solicitar los permisos respectivos $^{38}$. En idéntica situación, se decidió desarrollar otro turno el domingo 24 de diciembre, donde se contó con la participación de los disfraces ${ }^{39}$. Los payasos han representado toda una tradición y un aporte cultural en las festividades comunales $y$, desde luego, participaron y colaboraron con la reconstrucción del templo.

En definitiva, los turnos significaron una de las actividades más importantes en el proceso de reedificación pues, por un lado, generaron dinero y, por otro, contribuyeron a la cotidianidad pueblerina y a la sociabilidad. También favorecieron los lazos de unión y amistad con pueblos cercanos, lo cual representó una valiosa oportunidad para vigorizar y recrear la identidad local y, a la vez, fomentar valores.

\section{Reedificación del templo parroquial de San Juan: algunos detalles}

La reedificación del templo parroquial de San Juan inició de manera expedita pues, mediante oficio número 175 del 27 de setiembre de 1897, la Secretaría de Fomento 
solicitó al Director General de Obras Públicas disponer de un ingeniero para que diseñara, con la mayor brevedad, el plano del techo en hierro de la iglesia de San Juan ${ }^{40}$.

Los planos estuvieron elaborados el 10 de octubre de 1897; el ingeniero que los diseñó fue Augusto Fla Chebba ${ }^{41}$. Dichos planos fueron aprobados por la Junta Edificadora de la Iglesia de San Juan en sesión celebrada el 24 de octubre de $1897^{42}$. (Véase Fotografía No. 2, 3 y 4).

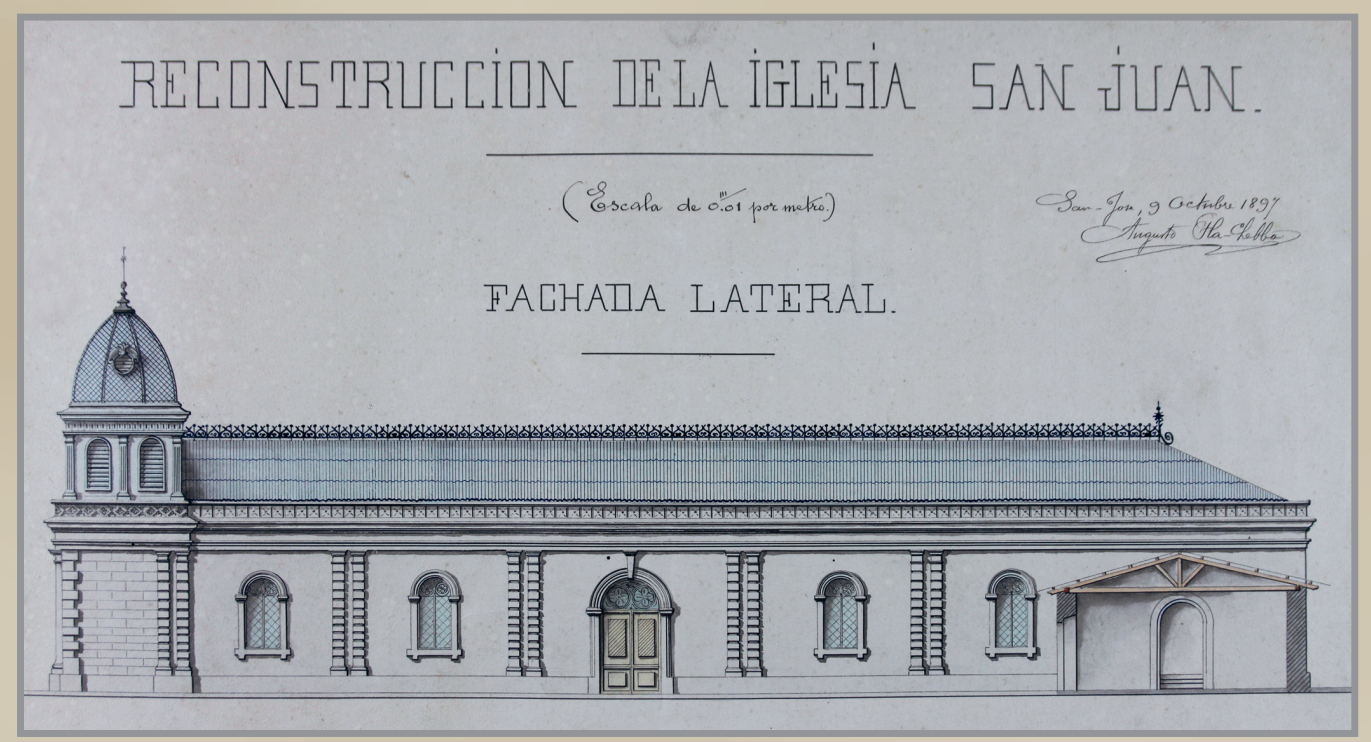

Fotografía 2.

Plano de Reedificación del Templo - octubre de 1897. Fuente: ANCR, M y $P, 317,1897$

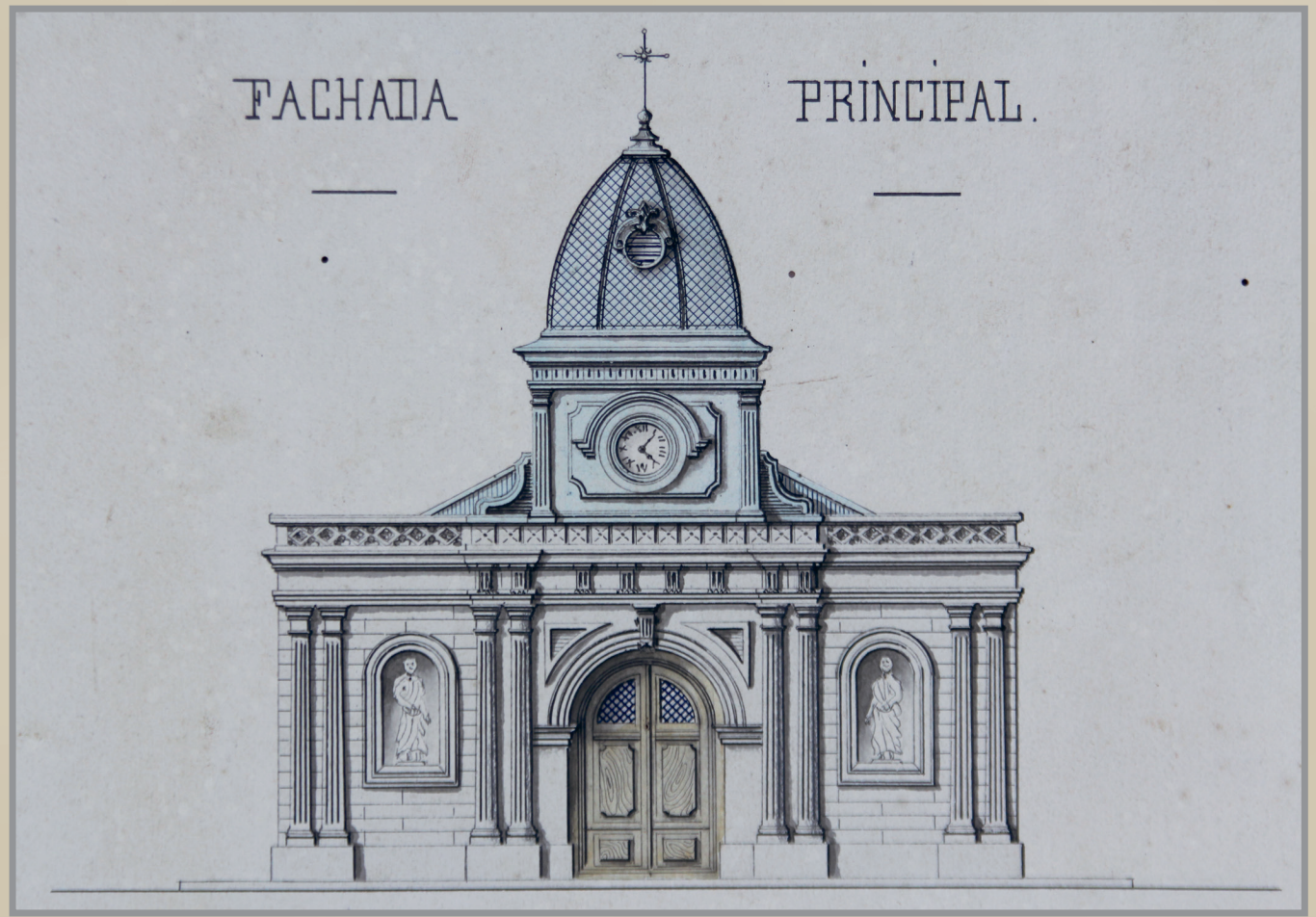

Fotografía 3.

Plano de Reedificación del Templo - octubre de 1897. Fuente: ANCR, M y P, 317, 1897 


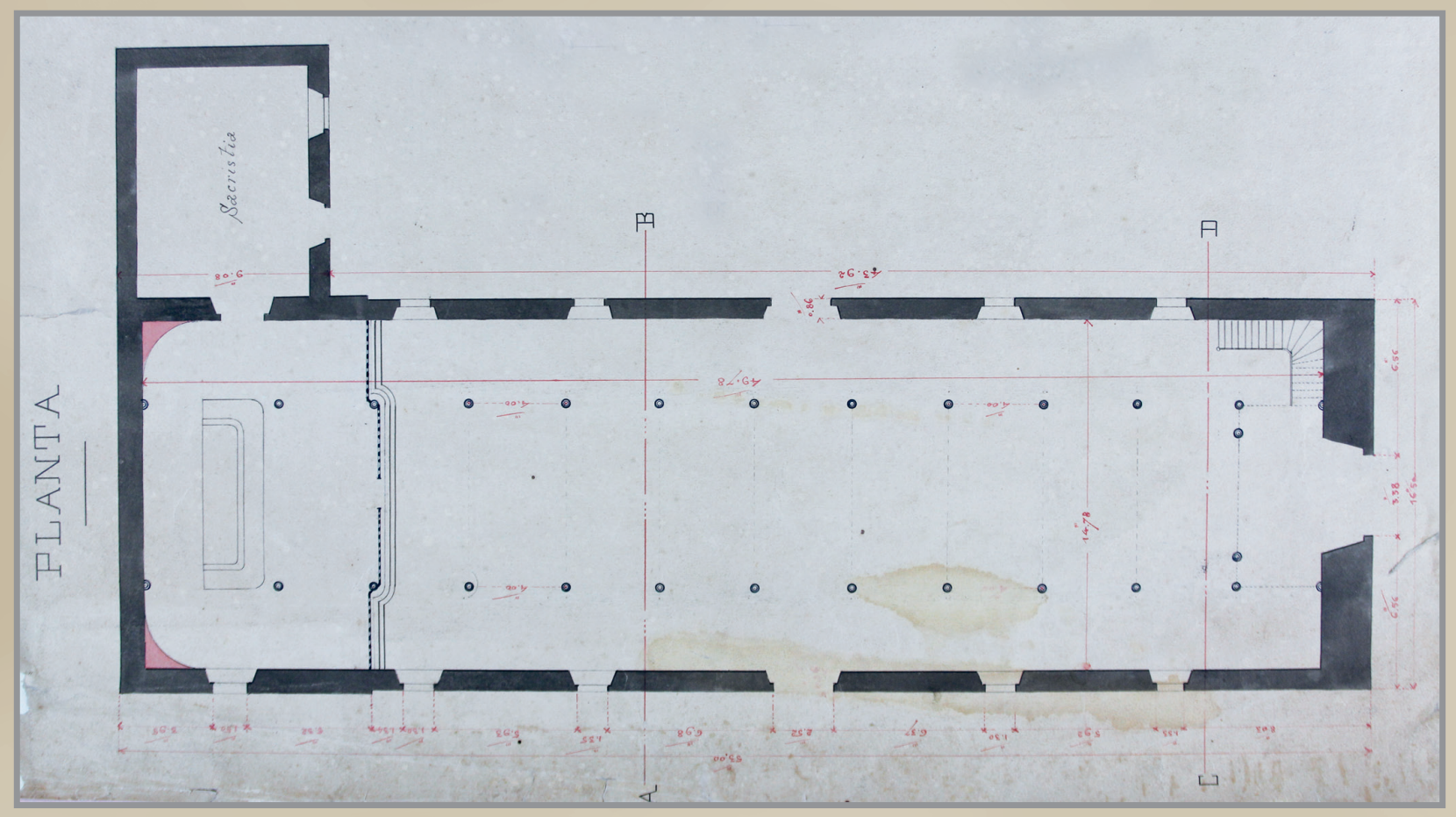

Fotografía 4. Plano de Reedificación del Templo - octubre de 1897. Fuente: ANCR, M y P, 317, 1897

También, en dicha sesión, se resolvió nombrar al señor Juan Bautista Quirós para que hiciera la solicitud de los materiales necesarios, que debían importarse. Además, se acordó construir en hierro las vidrieras y en madera las puertas del templo, e iniciar los trabajos de mampostería. A inicios de 1898, la Junta Edificadora convino -en sesión del 1 de enero- adquirir el armonio del Teatro Nacional, y encomendar la compra al presidente, padre Víctor de Gréve. A mediados de ese mes, es probable que el órgano pequeño ya se encontrara en San Juan, pues, para su adecuada conservación, se aprobó un reglamento ${ }^{43}$. También, en sesión de 30 de enero de 1898, la Junta Edificadora acordó construir el confesionario.

Para la reconstrucción se nombró un "director de los trabajos de la Iglesia". Aunque se desconoce quién fue el primero, lo cierto es que presentó renuncia a la Junta Edificadora a mediados de marzo de 1898, pues se nombró como nuevo director al señor José María Jiménez.

Para llegar a decisiones importantes, la Junta Edificadora tomó en cuenta la opinión del pueblo sanjuaneño, tanto en el caso del nuevo director como en lo que se refería a la contratación del señor Gastón Castex Marcaillon, de origen francés.

El señor Castex fue el constructor encargado de la reconstrucción. El contrato de reedificación del templo parroquial de San Juan, efectuado entre este señor y la Junta Edificadora, se firmó el 29 de marzo de $1898^{44}$. Previamente, el contrato fue revisado por el ingeniero Manuel Dengo, quien sugirió modificar el material y el modelo establecido por el contratista Castex ${ }^{45}$.

Algunos operarios que trabajaron en la reconstrucción del templo, según las fuentes consultadas, son los siguientes: José María Jiménez (director), Andrés Montero (albañil), Gerardo Vargas, Deodono Valenciano y Francisco Castex (ayudantes) y, finalmente, Guadalupe Jara y Francisco Masís ("mezclero") ${ }^{46}$.

La reedificación del techo de la iglesia de San Juan representó uno de los principales esfuerzos del pueblo sanjuaneño. En este sentido, es necesario destacar que la estructura del techo provino de Filadelfia, Estados Unidos ${ }^{47}$. (Véase Fotografía No. 5). 


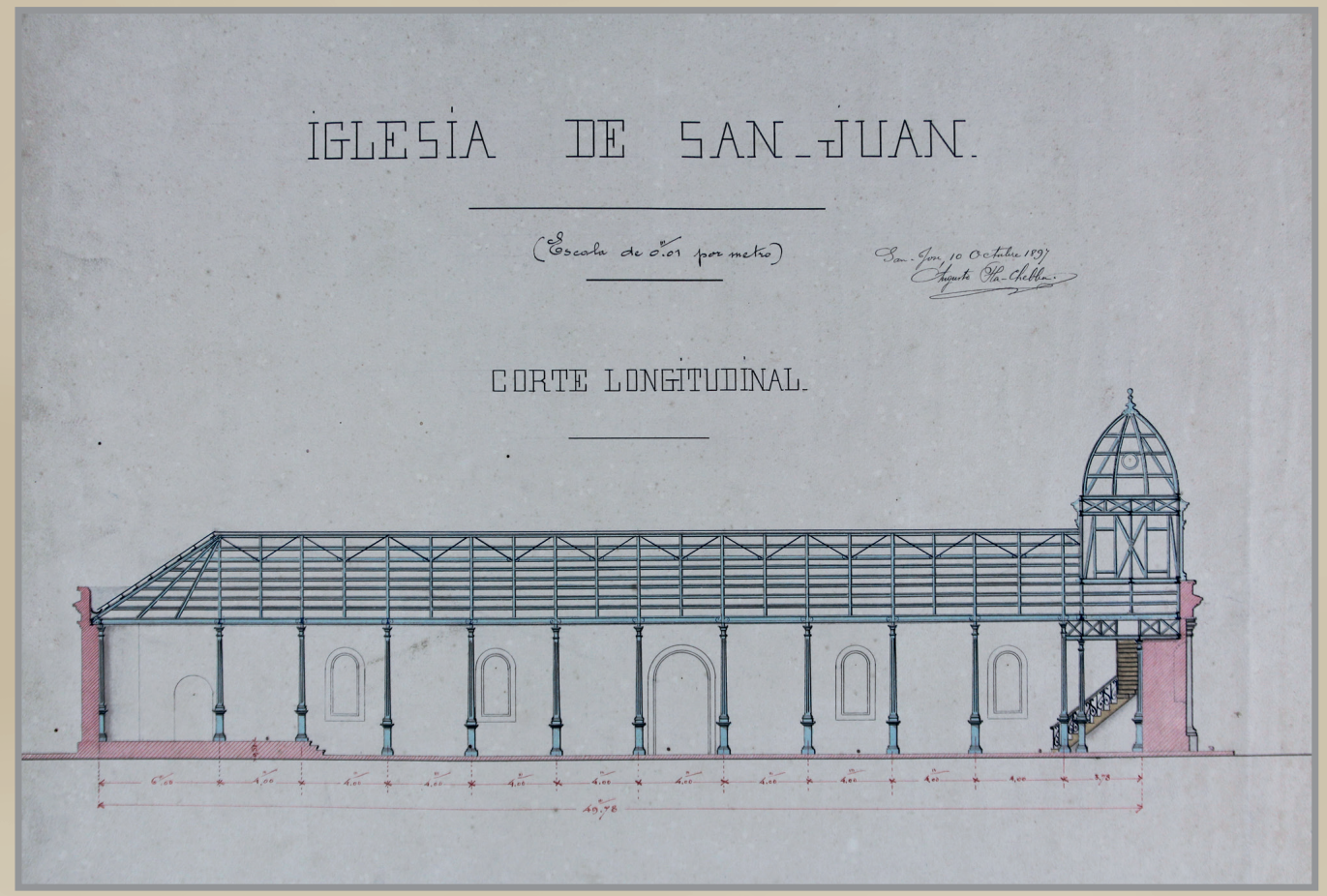

Fotografía 5. Plano de Reedificación del Templo - octubre de 1897. Fuente: ANCR,

M y $P, 318,1897$

Además, ante la imposibilidad de que los materiales fueran trasladados por el ferrocarril, desde San José a la estación en San Juan, estos fueron acarreados por carretas tiradas por bueyes. El 3 de agosto de 1898 Ilegaron a San Juan "el acero del techo y los cielos rasos", de la siguiente manera:

La buena voluntad de estos feligreses se manifestó otra vez en tal ocasión. Sólo un día de anticipación hubo para avisar a los hombres [que] alistaran bueyes y carretas para ir a la Aduana [...] Las carretas llegaron muy de mañana a San José en número sobrado, hubieron [sic] más de diez que nada tuvieron que cargar. Los bultos eran 45 , cada uno pesaba de 8 a 10 quintales. Este acero viene de la Casa S. H. Eller \& Compañía, de Filadelfia, Estados Unidos. (El Mensajero del Clero, 1898, pp. 343-344).

De igual forma, días después llegó "el hierro de la armazón" del techo del templo de San Juan. (Véase Fotografía No. 6 y 7). Esto aconteció el miércoles 24 de agosto de 1898:

El pueblo de San Juan está de plácemes por haber recibido el miércoles pasado el techo de su iglesia en construcción. ¡Valiente pueblecillo! Lleno de fe y entusiasmo ha reunido en muy poco tiempo más de 50.000 pesos para reparar con más belleza, gusto y lujo lo que el incendio destruyó en el templo del Señor. Así en algunos pueblos los reveses no desaniman, sino antes bien alientan los corazones cristianos. (El Eco Católico de Costa Rica, 1898, p. 315).

Otras noticias refirieron con mayor detalle el acontecimiento del arribo a San Juan del "hierro de la armazón" para el techo de su iglesia. Por ejemplo, el periódico El Mensajero del Clero (1898, p. 12) indicó que el miércoles 24 de agosto de 1898:

Grande fue el entusiasmo y alegría de ese generoso y católico pueblo. Cerca de 70 carretas que lo trajeron, fueron recibidas con el saludo de numerosos estampidos 
de pólvora y de vivas del pueblo. Este hierro viene de la casa Gara, McGinley y Cía. de Filadelfia, E.E.U.U [...] Fue ejecutado, según planos de aquí enviados, en 81 días. Según parecer de ingenieros consultados, es excelente el trabajo; uno de éstos observó: "Esta obra prueba que en los E.E. U.U. se trabaja mejor el hierro que en Bélgica". Gracias a la actividad del contratista, Sr. Gastón Castex y laboriosidad de los obreros, pudimos admirar montada la primera mancuerna el 26, segundo día después de la llegada, 15 días empleáronse en armar todo. En el momento en que escribimos estos renglones, falta poco para cubrir el techo de acero y ya está puesto como la tercera parte de los forros metálicos del cielo raso.

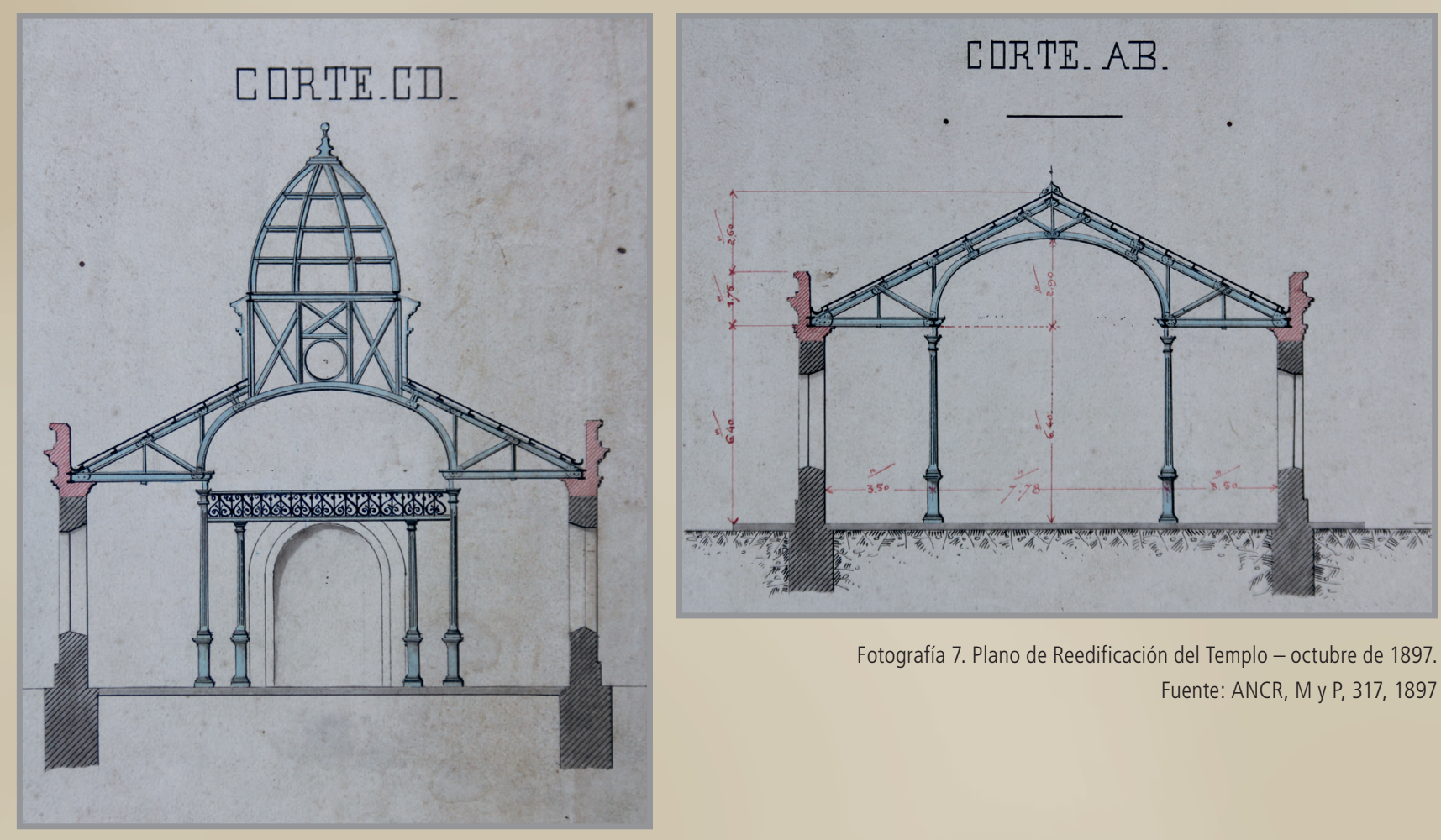

Fotografía 6. Plano de Reedificación del Templo - octubre de 1897. Fuente: ANCR, M y $P, 318,1897$
Las citas anteriores evidencian la voluntad, la fe en la unión, la generosidad, el desinterés, la disposición de colaborar y el espíritu caritativo del pueblo sanjuaneño, empeñado en levantar nuevamente el templo. También reflejan el entusiasmo y la alegría del "jvaliente pueblecillo!", así como el ambiente de fiesta y los "estampidos de pólvora"; pues, lejos de doblegarse ante la adversidad, los sanjuaneños celebraron la ocasión de reedificar y mejorar su templo. Así, es evidente que los infortunios y las desventuras no desmoralizan, sino que alientan y comprometen a redoblar esfuerzos.

El 25 de setiembre de 1898, la Junta Edificadora convino en iniciar las diligencias oportunas para que las columnas metálicas pudieran llegar a San Juan ${ }^{48}$. Al respecto la Junta Edificadora acordó:

En vista de que no se tiene conocimiento definitivo del paradero de las columnas metálicas del edificio de la Iglesia y puesto que hace algún tiempo que recibieron su 
desembarque en puerto Limón, se resuelve: nombrar una comisión compuesta de los señores presbítero don Víctor de Gréve, don José Saborío y don Gastón Castex para proceder al reclamo correspondiente sobre dicha cuestión ${ }^{49}$.

En realidad, con respecto a este asunto, la Junta Edificadora contrató "con el señor don Pablo Rodríguez la comisión del importe de las columnas metálicas para la reconstrucción de la iglesia al precio de $3 \% "{ }^{50}$. Sin embargo, al final, y no hallándose el señor Pablo Rodríguez en el país, sus representantes aumentaron la comisión acordada al $8 \%$ para luego reducirla al $5 \frac{1}{2} \%$, lo que trajo toda una contrariedad para la Junta Edificadora.

Al no aceptar, la Junta Edificadora, el cambio de condiciones por parte de los representantes del señor Rodríguez, estos últimos se negaron a entregar las columnas, por lo que la Junta Edificadora nombró comisión para buscar un defensor que reclamara legalmente ${ }^{51}$.

Por último, la Junta Edificadora resolvió, el 6 de noviembre de 1898, que el tesorero y el ecónomo se presentaran ante el señor Rafael Vargas: "... solicitando arreglo con dicho señor [Vargas], con respecto de la cantidad que el mismo reconoció para poder obtener la orden de entrega de las columnas metálicas del edificio de la iglesia" 52 .

Muchos otros sanjuaneños, al igual que el señor Rafael Vargas, colaboraron gustosos con la reconstrucción de la iglesia. Así, en el artículo $2 .^{\circ}$ de la sesión del 4 de diciembre de 1898, la Junta Edificadora acordó lo siguiente:

En vista de que para pagar algunos de los elementos, que se necesitan para la redifidicación [sic] del mismo edificio en los E.E.U.U., el erario de esta corporación se halla insuficiente, se exita [sic] a don Salvador Rodríguez, para que en dicho sentido que por medio de café exportable [texto incompleto] [...] quien acepta tal proposición" ${ }^{53}$.

Una vez que el techo estuvo construido, los sanjuaneños se dedicaron a reedificar otras áreas de su templo. Por ejemplo, en sesión del 6 de noviembre de 1898, la Junta Edificadora convino en: "Autorizar al señor Presidente de la misma [presbítero Víctor de Gréve] para que respectivamente consulte con el Sr. Gastón Castex, a fin de que éste haga el pedido del reloj y campana que el Sr. Marcelino Rodríguez ha ofrecido obsequiar para el uso de esta Parroquia"54.

A escasos 19 días de la Navidad; es decir, el 6 de diciembre de 1898, el cura de San Juan solicitó al Secretario de Estado en el despacho de Hacienda, la exención de los derechos de aduana de unos materiales destinados a la reedificación del templo sanjuaneño. Alegaba que solicitaba la exención "por ser gracia concedida a los materiales para dicha clase de edificios".

Los materiales que llegaron a Limón el 29 de noviembre de 1898 en el vapor Venezuela, eran 68 barriles de cemento y 43 ladrillos ${ }^{55}$.

Al año siguiente, solicitando la exención de los derechos de aduana, y basado en la misma justificación, el cura indicó en nota fechada del 7 de marzo de 1899, que el vapor Alleghany había llegado a Limón el 25 de febrero de 1899, trayendo para la iglesia de San Juan "23 bultos pinturas" 56 .

El 25 enero de 1899 la Junta Edificadora, en sesión extraordinaria, informó del dinero invertido hasta ese momento en la reedificación de la iglesia de San Juan, indicando lo siguiente:

Se procedió a la revisación [sic] de cuentas, para averiguar el resultado del gasto de dinero que ha hecho con motivo a los trabajos de Iglesia y resultó aproximadamente la cantidad de (10000) diez mil pesos, inclusive la pintura que se puso al edificio 
antes del incendio pasado y la compra del armonio que actualmente se usa, esto de cuenta de la Junta expresamente y casi la cantidad de (42000) cuarenta y dos mil pesos de cuenta del contrato celebrado con el señor Gastón Castex ${ }^{57}$.

A mediados del mes de junio de 1899, la reconstrucción se centró en ciertos detalles al interior del templo: se adquirió la madera para construir "el piso del coro" y se edificó la baranda metálica del bautisterio. En julio de dicho año, la Junta Edificadora conoció sobre el mobiliario y las puertas del templo.

En síntesis, para mediados de 1899 la obra avanzó de forma importante en lo que se podrían Ilamar "detalles": colocación de las aldabas de las puertas, acabados de la fachada, colocación de lo que faltaba del pavimento (piso) -importado de una fábrica en Filadelfia, Estados Unidos-, pintura de las columnas metálicas y construcción de desagües. También se construyó una gruta, Ilamada "gruta de Lourdes", y se colocaron dentro del templo las imágenes del Sagrado Corazón de Jesús y de María en pedestales fijados en las "dos primeras columnas del Presbiterio".

En medio de estas tareas surgió, a mitad de 1899, un conflicto entre la Junta Edificadora y el señor Gastón Castex Marcaillon por incumplimiento de contrato ${ }^{58}$. A pesar de esto, la labor de Castex continuó y el mencionado conflicto se dirimió en las instancias judiciales, como se verá más adelante.

A inicios de noviembre de 1899 faltaban por concluir los siguientes detalles: pintar la pila bautismal y algunas paredes de la "gruta de Lourdes", arreglar definitivamente el techo (presentaba algunas goteras) y terminar el púlpito y el zócalo59.

En los últimos meses de 1899, se observa un esfuerzo por parte de la Junta Edificadora de la iglesia de San Juan en recaudar el dinero prometido mediante las suscripciones, pues es evidente la reedificación del templo en un alto porcentaje y la necesidad de cancelar muchas deudas que dicha obra conllevaba. Gracias a la voluntad, al espíritu caritativo y al esfuerzo de los sanjuaneños, y a la solidaridad y colaboración brindada por los pueblos vecinos, a finales de 1899 el templo de San Juan estuvo bastante reedificado y dispuesto al culto religioso. (Véase Fotografía No. 8, 9 y 10).

Fotografía 8.

Templo Parroquial de

San Juan de Tibás.

Fuente: Jiménez

Rodríguez, Luz

Marina. Monografía de Tibás (Tesis de graduación, Escuela de Pedagogía: UCR, 1947) p. 59

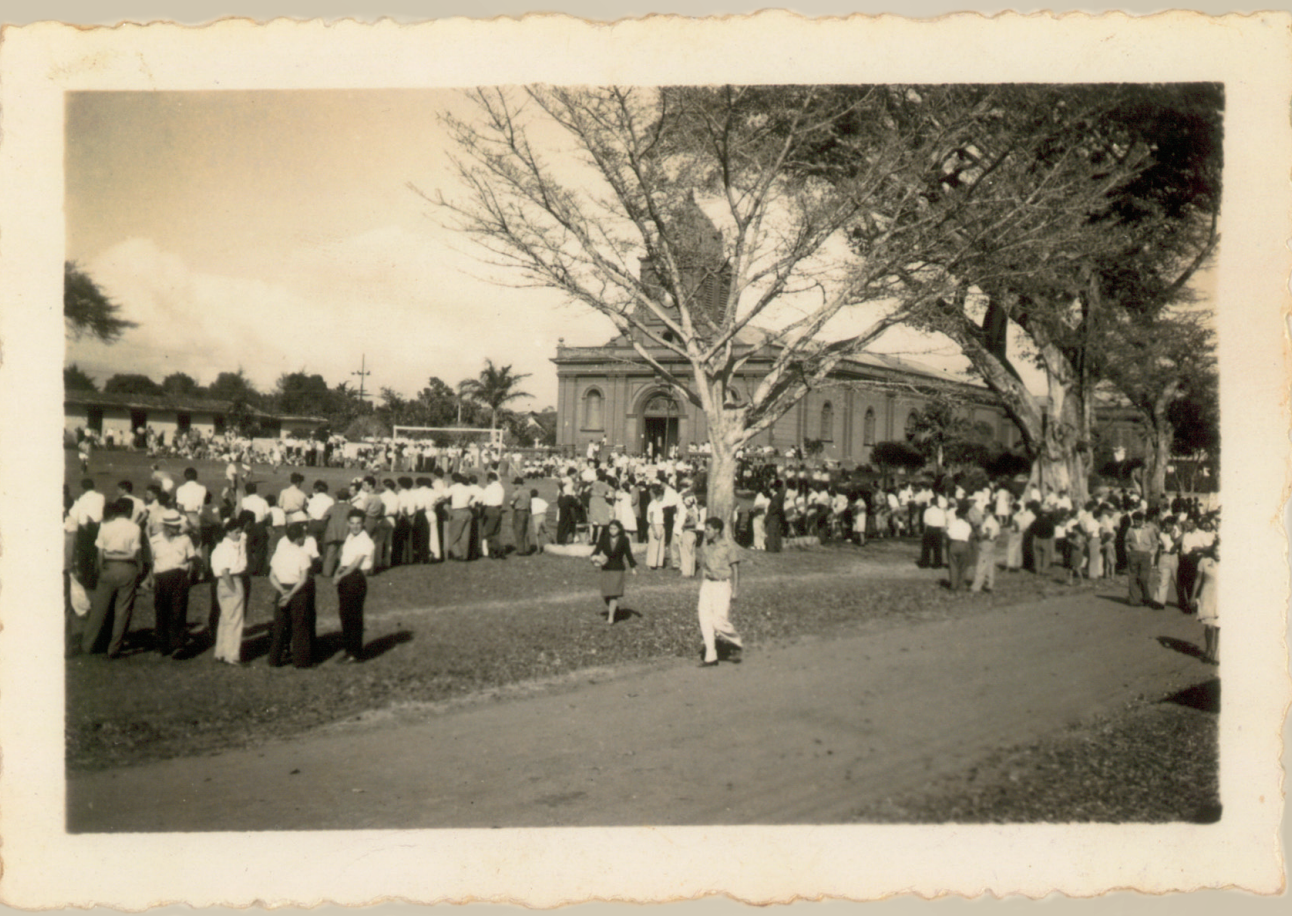


En la fachada del templo, precisamente debajo de la torre y en la parte superior de la puerta, se escribió en latín lo siguiente: "Incendio destructa A. D. MDCCCXCVII Cultui redita A. D. $M D C C C X C I X "$ " (Destruida por un incendio en el Año del Señor 1897. Dedicada otra vez al culto en el Año del Señor en 1899$)^{60}$. La idea fue del presidente de la Junta Edificadora, el presbítero Víctor de Gréve Plum, quien consideró importante "inscribir en la fachada de la torre de la iglesia, un símbolo que denote destrucción y redificación [sic] de este edificio, pero en latín"61. Esta indicación, que recordaba el siniestro y la fraternidad y colaboración del pueblo sanjuaneño en su reedificación, desapareció a finales del siglo XX.

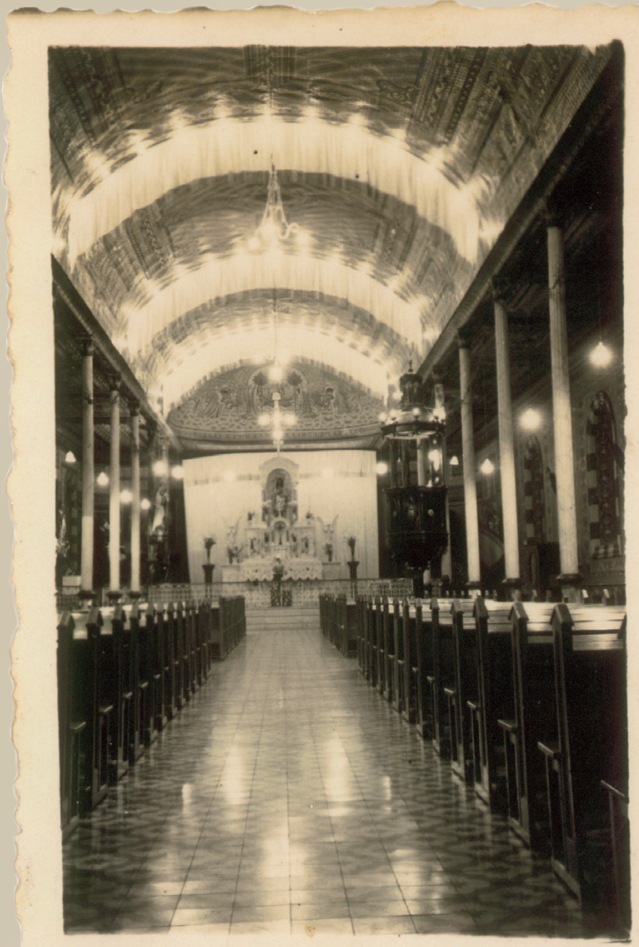

Fotografía 9. Vista Interna del Templo

Fuente: Jiménez

Rodríguez, Luz

Marina. Monografía

de Tibás (Tesis de graduación, Escuela de Pedagogía: UCR,

1947) p. 63

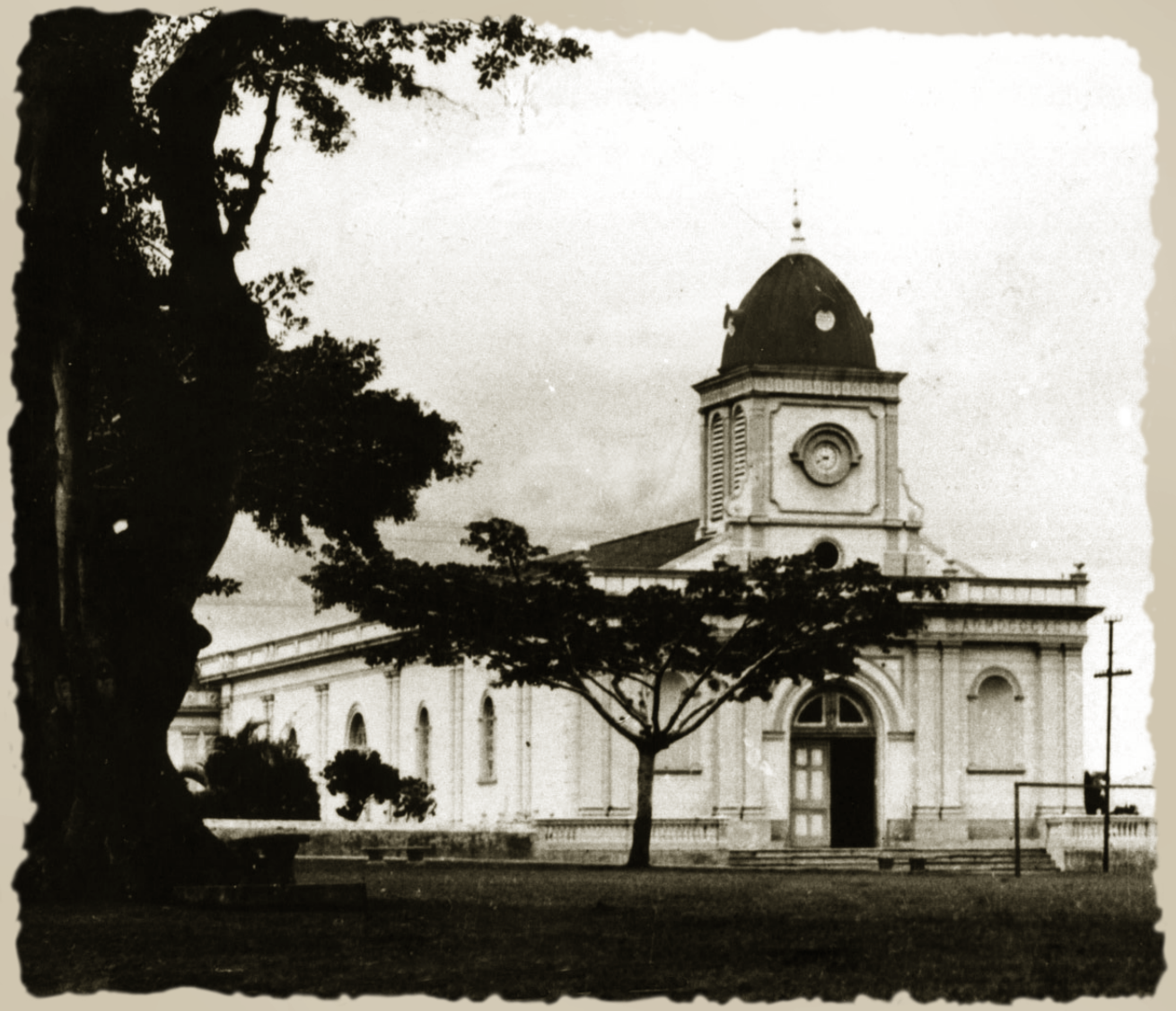

Fotografía 10. Templo Parroquial de San Juan de Tibás Fuente: ANCR, Ft, 7183, 1910-1963 
Aunque el templo fue nuevamente dispuesto al culto a finales de 1899, la reconstrucción continuó pues las fuentes dejan evidencia de que faltaban por concluir algunos detalles. De igual manera, continuaron desarrollándose los turnos y las rifas como actividades generadoras de recursos económicos. En este sentido, se menciona el turno efectuado el domingo 12 de mayo de 1900.

Los trabajos que faltaban por concluir eran de mampostería y pintura. En cuanto a lo último, las fuentes mencionan como pintor de la iglesia al señor Evangelista Jara $^{62}$. Otro detalle que faltaba eran las aceras y, para su construcción, algunos miembros de la Junta Edificadora se trasladaron a Cartago para "solicitar allí el cordón de piedra necesario".

Asimismo, en el primer semestre del año 1900 se colocó el pararrayos y el reloj. En cuanto al pararrayos, los trámites para su adquisición iniciaron en enero de 1900 y la gestión de desembarque, dos meses después. En sesión ordinaria, celebrada el 25 de marzo de 1900, la Junta Edificadora exhortó al contratista (señor Gastón Castex) a "abreviar la colocación necesaria" del pararrayos ${ }^{63}$.

El reloj y la campana fueron obsequiados por el señor Marcelino Rodríguez; sin embargo, la Junta Edificadora se vio en la necesidad de tomar dicho dinero y enfrentar el pago de otras obligaciones de la propia reedificación, reconociendo que debía reponer dicho dinero para la finalidad que el señor Rodríguez había expresado ${ }^{64}$.

Por ello, habiendo obtenido recursos económicos mediante el turno efectuado el domingo 12 de mayo de 1900, la Junta Edificadora acordó, en sesión ordinaria del domingo 20 de mayo de 1900, lo siguiente:

Que del dinero así obtenido, el señor Tesorero ponga a la orden del señor Presidente la cantidad de ocho cientos y resto de pesos, para el encargo y compra del reloj donado a la Iglesia por don Marcelino Rodríguez, lo que por haber necesitado del fondo respectivo aún no se había hecho"65.

Durante 1900 continuó la reedificación, así como el conflicto entre la Junta Edificadora y el contratista. En este sentido, la Junta acordó en sesión ordinaria, celebrada el 17 de junio de 1900, liquidar el contrato y, en la siguiente sesión, contratar un abogado para que legalmente se encargara del asunto ${ }^{66}$.

El abogado hizo su trabajo, pues en dicho mes de junio el cura Víctor De Gréve y los señores Salvador Rodríguez Coto y Baltazar Valenciano Segura, presidente y vocales respectivamente de la Junta Edificadora, solicitaron ante el Juzgado Primero Civil de San José, embargo provisional en bienes del señor Gastón Castex por la suma de mil quinientos pesos ${ }^{67}$.

El embargo preventivo llegó a su término cuando la Junta Edificadora y el señor Castex convinieron en que la junta recibiría de Castex el mosaico sobrante, empleado en la reparación del "pavimento" de la iglesia del Carmen una vez concluida esa reparación ${ }^{68}$.

Con ello se cerraba el capítulo de la reedificación del templo parroquial de San Juan, templo de gran tradición, historia e importancia, que marca y determina la evolución territorial-eclesiástica de la zona de El Murciélago y que incide posteriormente en la evolución político-administrativa. (Véase Fotografía No. 11, 12$, y 13$)$. 

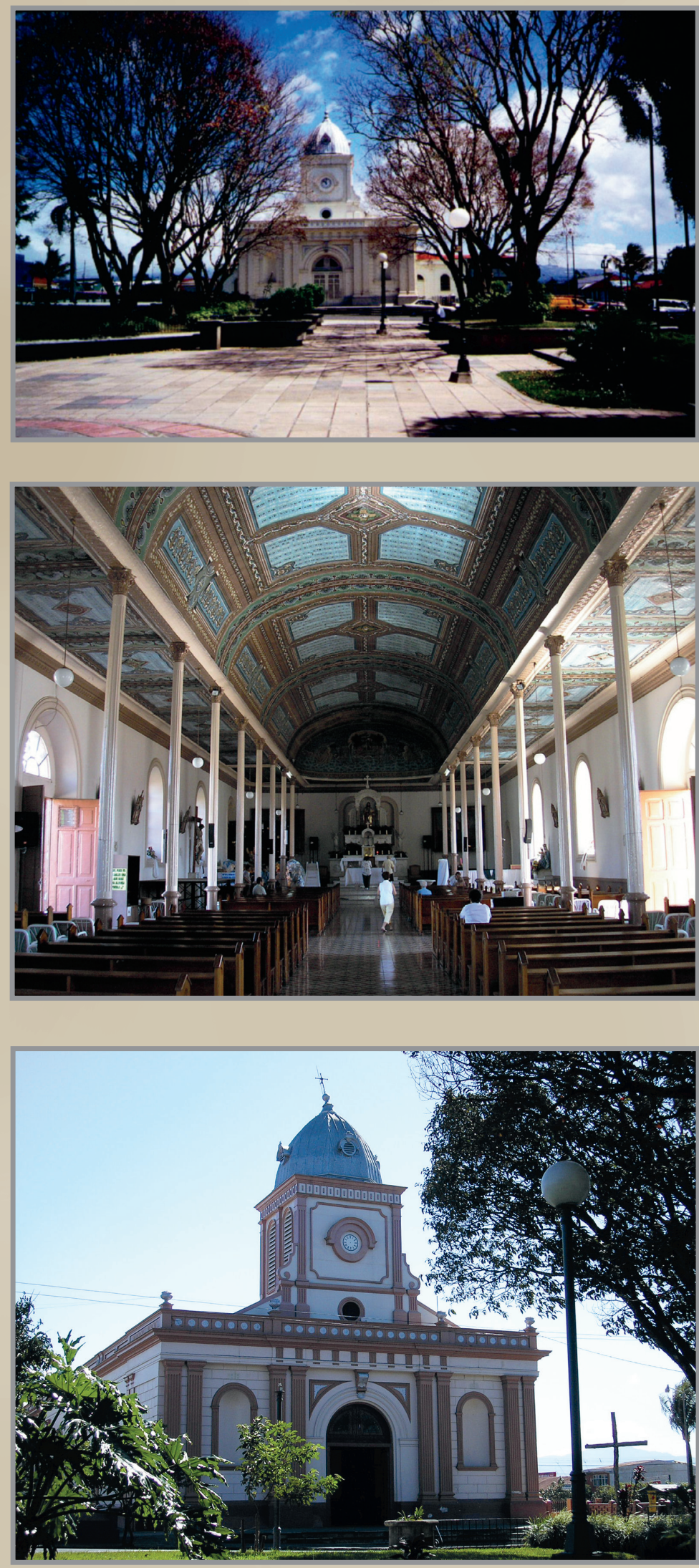

Fotografía 11. Templo Parroquial de San Juan de Tibás- enero de 2001 Fuente: Campos Ramírez, Jafeth. "Archivo fotográfico personal"

Fotografía 12. Vista Interna del Templo - diciembre de 2006 Fuente: Benavides Barquero, Manuel. "Archivo fotográfico personal"

Fotografía 13. Templo Parroquial de San Juan de Tibás - diciembre de 2006 Fuente: Benavides Barquero, Manuel. "Archivo fotográfico personal" 


\section{Del pasado al presente: la última restauración del templo parroquial de San Juan}

Entre 2008 y 2009, la parroquia de San Juan de Tibás y su cura párroco, Presbítero Roberto Salazar Rodríguez, decidieron pintar el templo e imprimirle una nueva imagen. Las labores consistían en eliminar todas las capas anteriores de pintura e impermeabilizar, sellar y pintar desde el repello original. Estas labores eran necesarias y válidas, en especial para obras como el templo de San Juan de Tibás, que había tenido una gran cantidad de aplicaciones de pintura.

Al iniciar con esta tarea de mantenimiento, al preparar la superficie de las paredes externas (pulimentar y lijar), se observó que la mayoría de los viejos repellos se encontraban sueltos o desintegrados, por lo que se estaban desprendiendo. Esto causó gran alarma, pues era evidente que el templo estaba debilitado estructuralmente y que urgía una profunda restauración.

El presbítero Salazar Rodríguez solicitó a la comunidad la colaboración de algún arquitecto, para conocer el verdadero estado del templo. El Arquitecto Mario Rivas Vargas contactó al presbítero y se hizo cargo de la tarea; la cual, al principio, parecía sencilla pero al final resultó una labor titánica.

Así, se realizó un estudio técnico de las paredes del templo. En febrero de 2009, los resultados fueron recogidos en un documento titulado: "Informe Técnico acerca de las Condiciones Constructivas de los Repellos del Templo de la Parroquia San Juan Bautista de Tibás".

El mencionado estudio técnico confirmó un panorama poco halagador: una vez que fueron eliminadas las diferentes capas de pintura, se comprobó que los repellos de las paredes estaban pulverizados y en muy mal estado. Se procedió a localizar las áreas más afectadas y "se logró determinar que más del $80 \%$ del área total de los repellos exteriores de las paredes del templo estaba colapsada". (Rivas Vargas y Asociados S. A., 2009, p. 2). (Véase Fotografía No. 14 y 15).

Fotografía 14. Repello en mal estado - 2009.

Fuente: Rivas Vargas y Asociados S. A. "Archivo fotográfico"

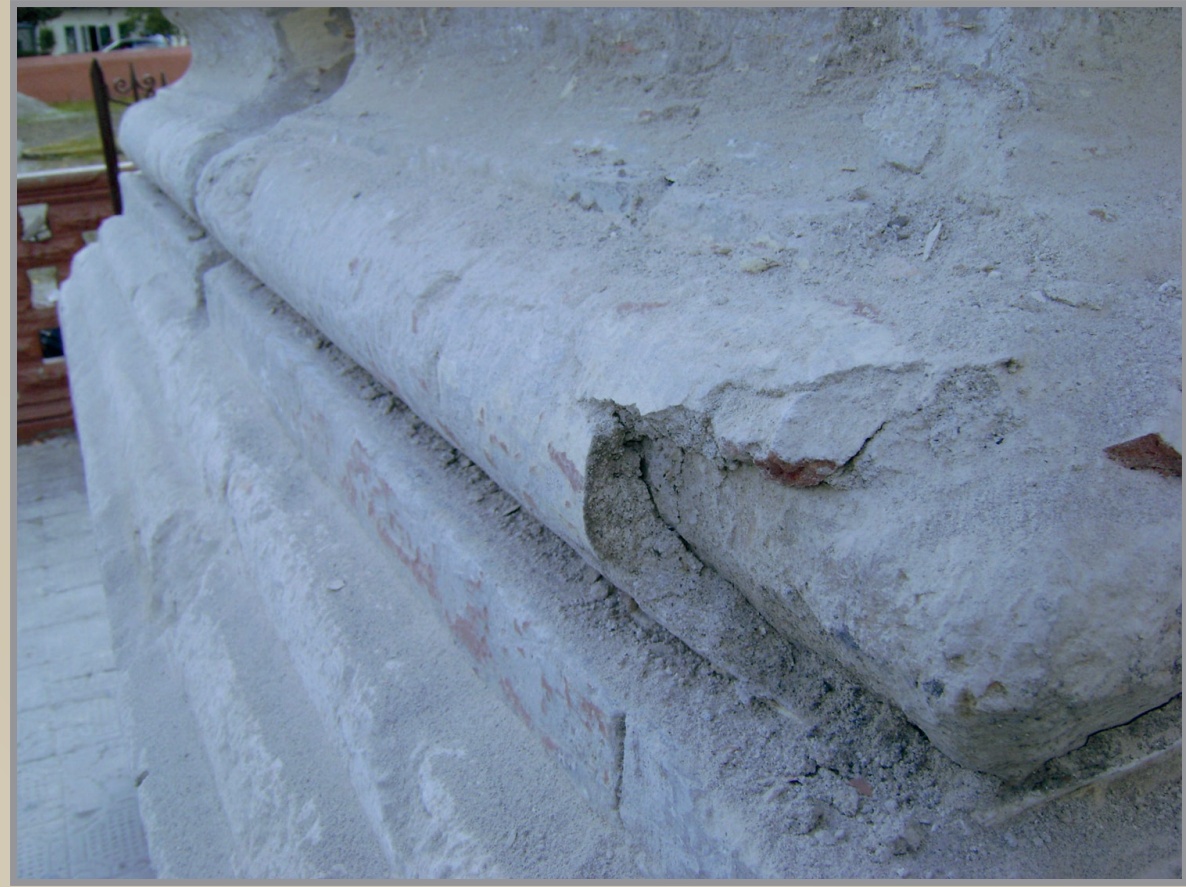


Además, se determinó que eran varios los eventos de reparación de los repellos; incluso cuando estaban agrietados o desprendidos, le fueron colocados encima nuevas capas. Esta situación generó que las paredes presentaran diferentes calidades de repellos. Los de mayor predominancia eran los de arena y cal, los cuales también habían agotado su vida útil. Los repellos fueron aplicados sobre la estructura principal de las paredes y en los marcos de las puertas y ventanas. Probablemente, eran los mismos (en calidad y edad) a los que existían dentro del templo.

En este sentido, los repellos del interior del templo presentaban problemas similares, aunque la gravedad no fuera tan evidente, a los del exterior, especialmente debido a que las condiciones de intemperismo son diferentes; es decir, las paredes externas reciben directamente las constantes y cambiantes condiciones del clima, entre otros factores.

Por todo ello, la parroquia de San Juan de Tibás y su cura párroco, contando con la anuencia de la Curia Metropolitana, decidieron restaurar el templo. Este proceso no solamente implica un asunto de orden económico, sino también histórico, patrimonial y cultural, y, por supuesto, arquitectónico y comunal.

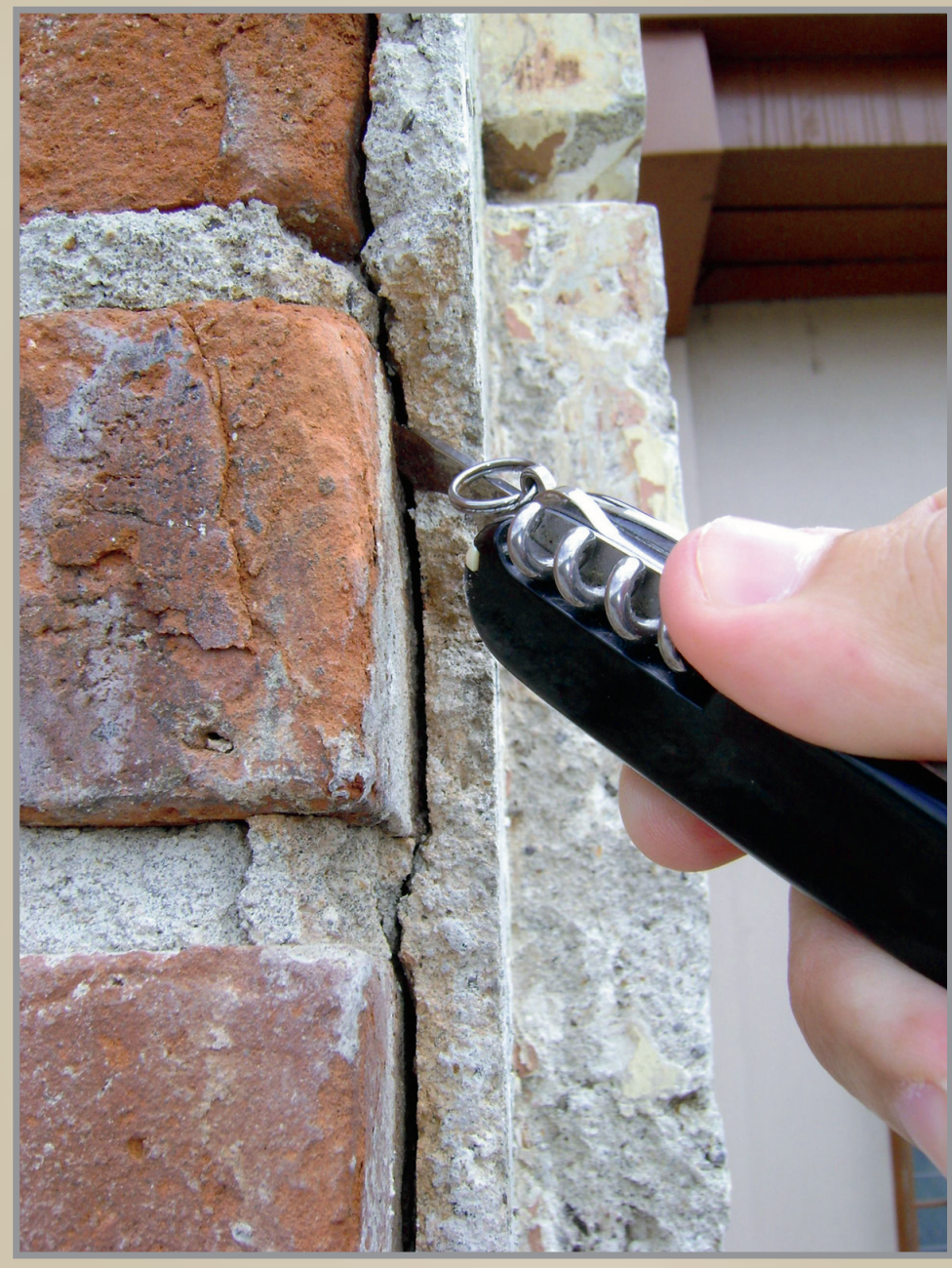

Fotografía 15. Repello en mal estado - 2009. Fuente: Rivas Vargas y Asociados S. A. "Archivo fotográfico"

Uno de los principales desafíos de la restauración radica en que en el exterior del templo existen diversos detalles arquitectónicos de gran exquisitez, que es imprescindible conservar, pues el templo forma parte intrínseca de la identidad tibaseña.

El proceso de restauración consistió en realizar el levantamiento arquitectónico, luego el rescate de las molduras y relieves, y, finalmente, el detalle de las puertas. En este proceso, las molduras y demás elementos arquitectónicos fueron reproducidos en tamaño natural en fibra de vidrio, pues la reparación de los repellos afectaría estos detalles; además, el proceso estaba enfocado en restaurar y conservar fielmente todos los detalles del templo, para mantener el mismo lenguaje arquitectónico ${ }^{69}$. (Véase Fotografía No. 16 y 17).

También, se observó que las diferentes ocasiones en que se pintó el templo, se afectaron los detalles; es decir, las diversas manos de pintura ocultaron muchos de los detalles o elementos arquitectónicos.

Así, por ejemplo, durante el proceso restaurativo se encontró, bajo la pintura, la inscripción en latín colocada en la fachada del templo a finales de 1899, que recordaba el incendio y la destrucción de 1897, y la posterior reedificación de 1899. (Véase Fotografía No. 18). 
Fotografía 16. Rescate de molduras y relieves - 2009 Fuente: Rivas Vargas y Asociados S. A. "Archivo fotográfico"

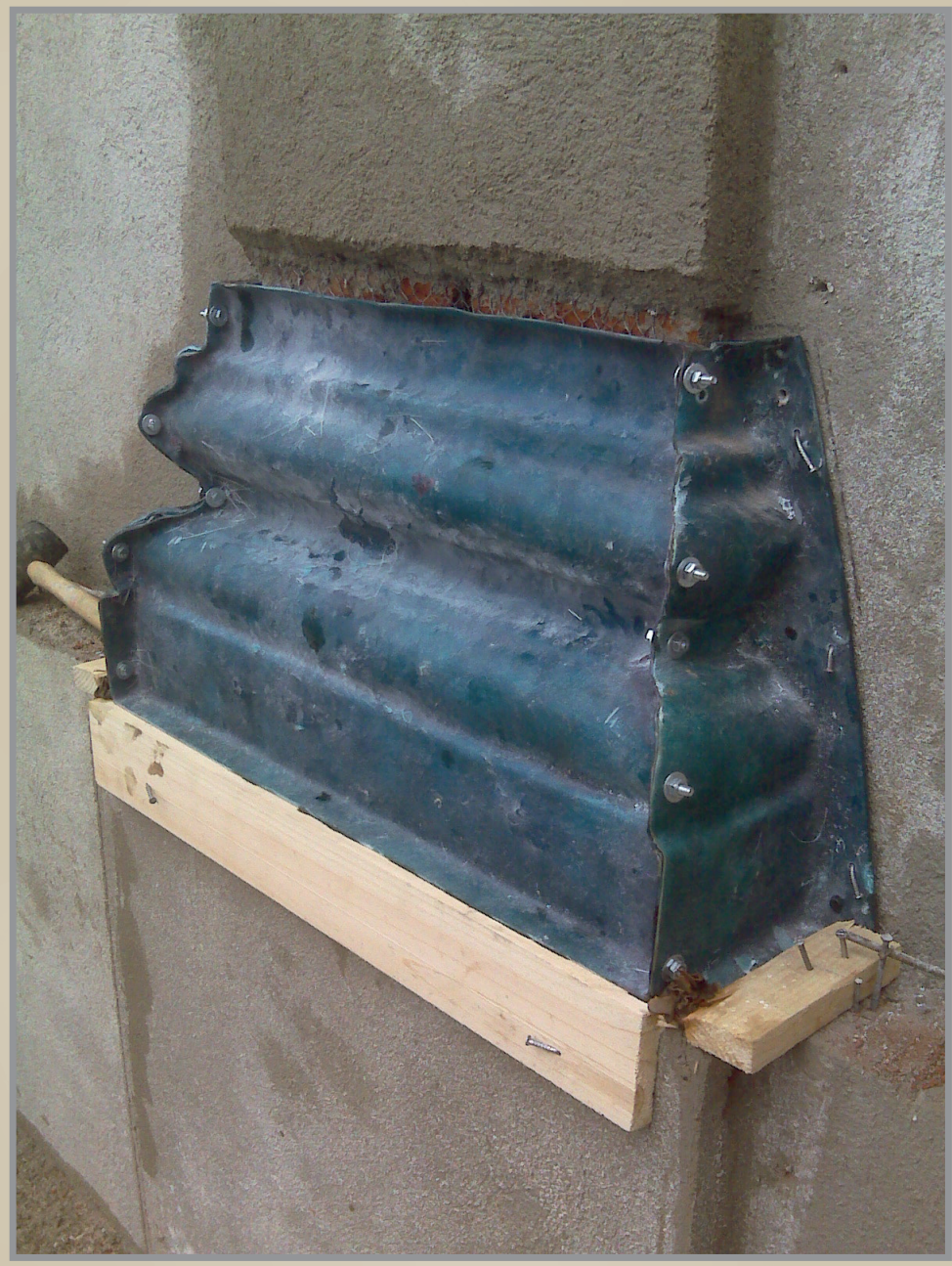

Fotografía 17. Rescate de molduras y relieves - 2009 . Fuente: Rivas Vargas y Asociados S. A. "Archivo fotográfico"

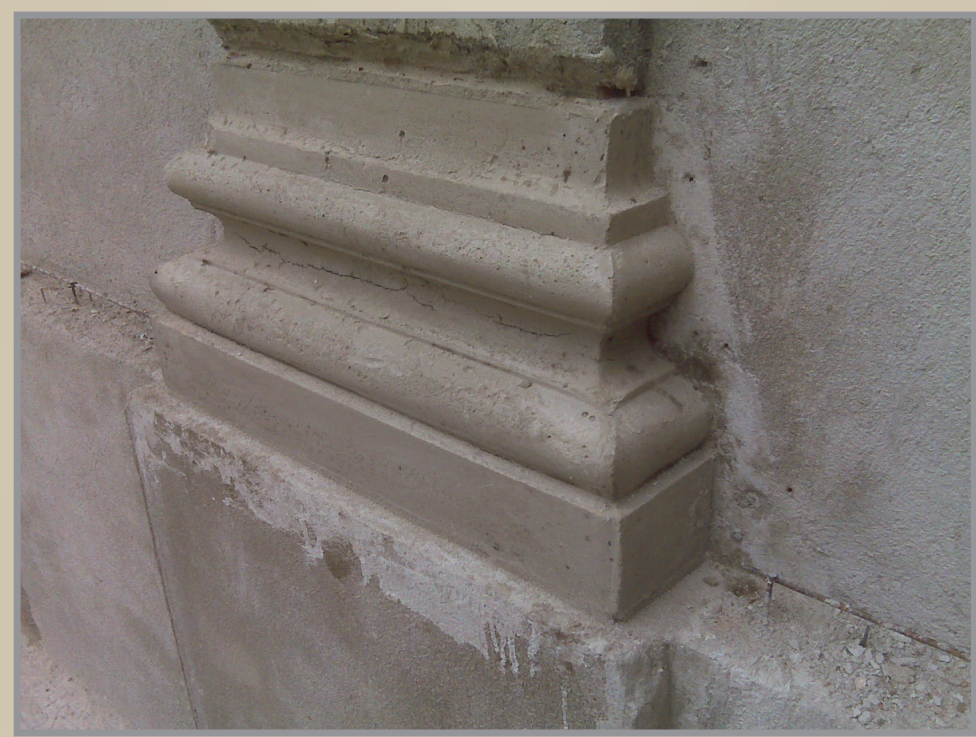




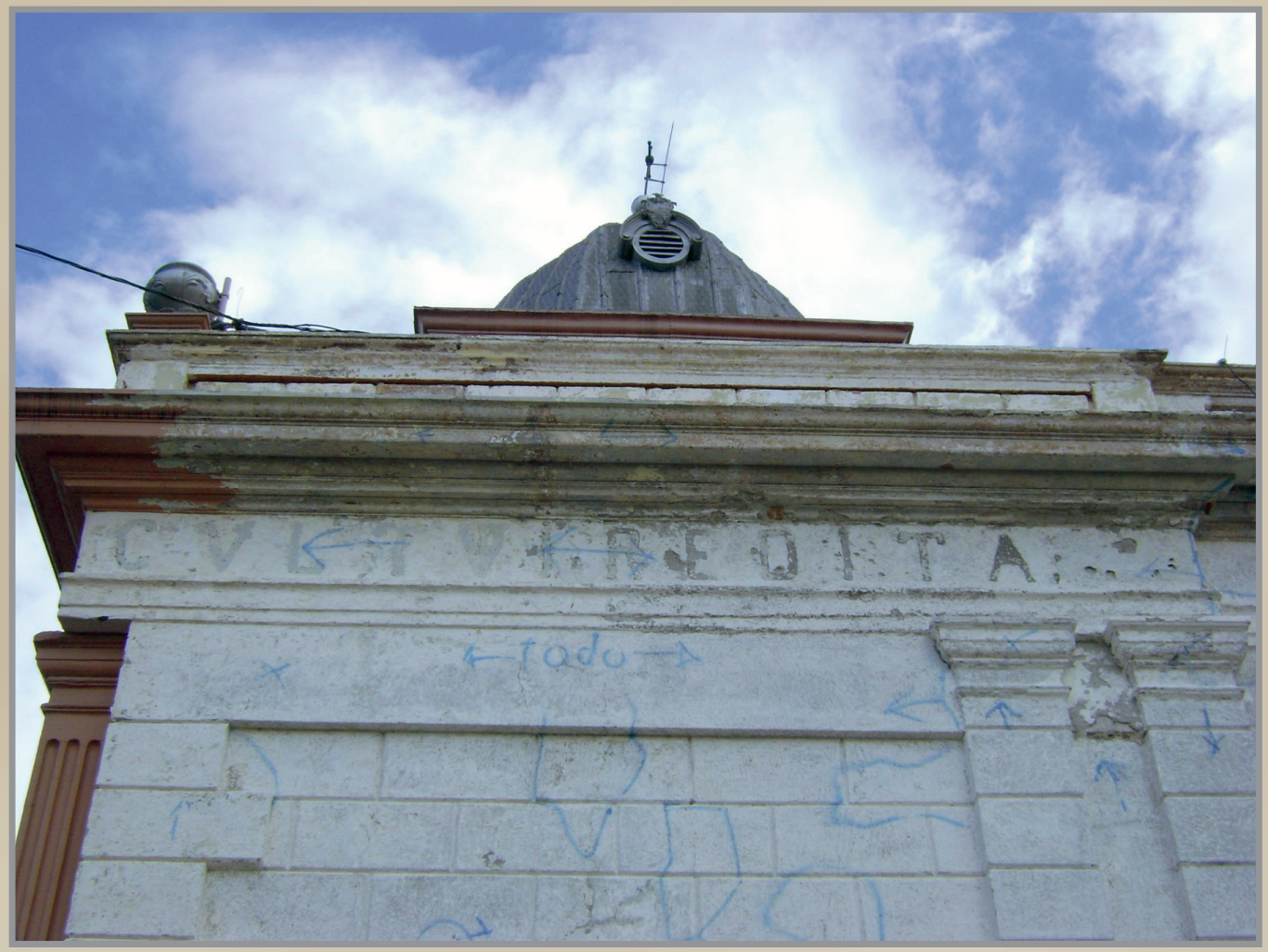

Se trata de la misma inscripción que fue colocada por iniciativa del presidente de la Junta Edificadora, el presbítero Víctor de Gréve Plum, con el propósito de recordar el siniestro, pero sobre todo de celebrar la fraternidad y colaboración del pueblo sanjuaneño y de las comunidades vecinas en la reedificación del templo. Ante el "descubrimiento", ha surgido en la comunidad el interés y el deseo por rescatar la inscripción, lo cual hoy es una realidad (noviembre de 2013).

Por otra parte, se encontró otro elemento que contribuyó a afectar las paredes del templo: muchas canoas y bajantes ocultos (dentro de las paredes) habían agotado su vida útil y dejaban pasar la humedad a las paredes, debilitándolas enormemente. Los elementos más críticos durante la restauración fueron las doce columnas, que se ubican sobre relieve de las paredes externas, las puertas, las ventanas y la fachada, pues presentan relieves de orden arquitectónico muy importantes que deben mantenerse (Véanse Fotografías de 19 a 23).

En cuanto a la fachada, se restauraron las molduras, se impermeabilizó para protección y, como se indicó líneas atrás, se rescató la inscripción que recordaba el incendio y destrucción de 1897 y la posterior reedificación de 1899. La fachada se mantiene sin color en espera de que se tome alguna decisión.

También las paredes internas fueron restauradas, prácticamente con el mismo tratamiento de las externas. Se trabajó en los repellos que estaban en mal estado: se eliminaron, se colocó "malla electro soldada" y luego un repello de alta resistencia. (Véase Fotografía No. 24). Además, se picó la base de las paredes, desde el piso hasta aproximadamente un metro de altura y se coclocó un repello de alta resistencia. Se diseñó tubería oculta (dentro de las paredes) para la distribución eléctrica, el audio y vídeo. Finalmente se pintó. 
Fotografía 19. Columnas deterio-

radas -2011 .

Fuente: Rivas

Vargas y Asociados

S. A. "Archivo

fotográfico"

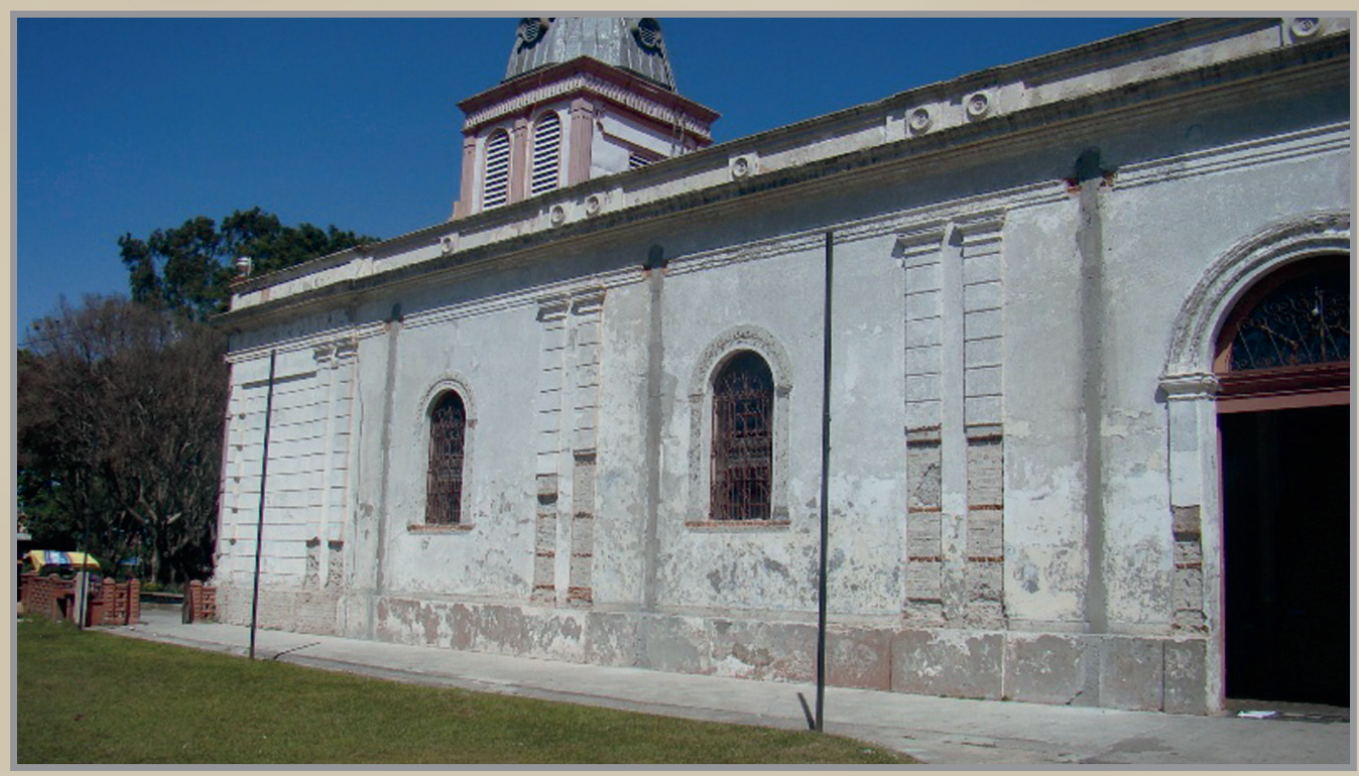

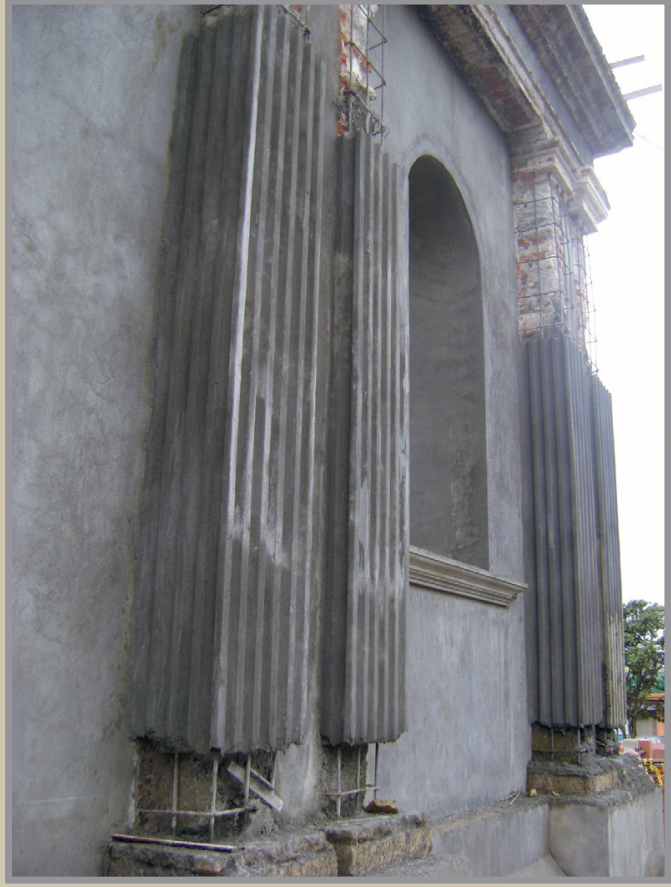

Fotografía 20. Reconstrucción de columnas - 2010. Fuente: Rivas Vargas y Asociados S. A. "Archivo fotográfico"

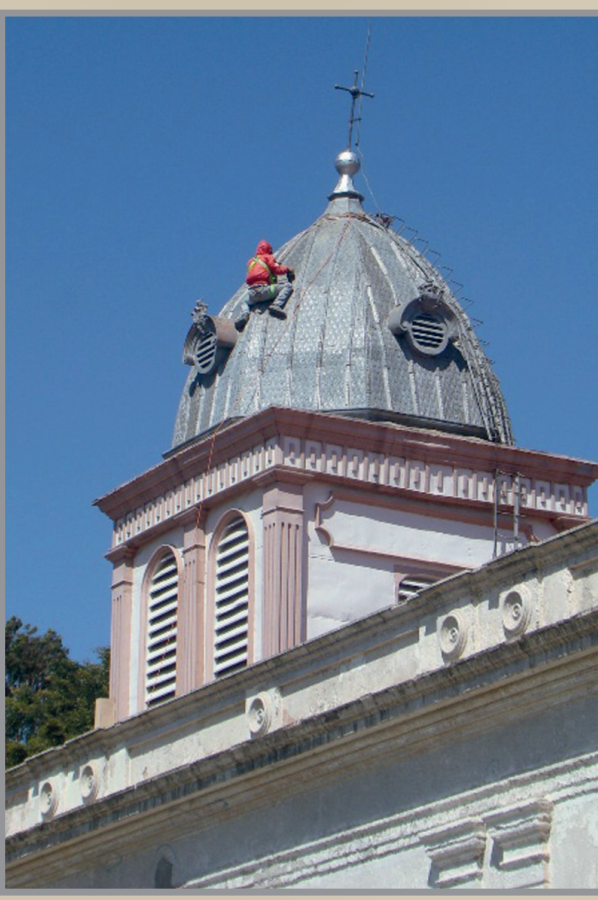

Fotografía 21. Reconstrucción - 2011. Fuente: Rivas Vargas y Asociados S. A. "Archivo fotográfico"

En la actualidad (noviembre de 2013), se trabaja en la modernización del sistema eléctrico y en las medidas contra incendios (detectores de calor, extintores y rotulación), labores que se encuentran muy avanzadas. El proceso restaurativo contempla otros sectores, como la sacristía y la capilla del santísimo, obras desarrolladas en un $90 \%{ }^{70}$. Por último, queda por restaurar las aceras perimetrales, el parqueo y los baños. Además, se analiza la iluminación interior, así como la exterior en sus costados norte, sur y la fachada ${ }^{71}$. 


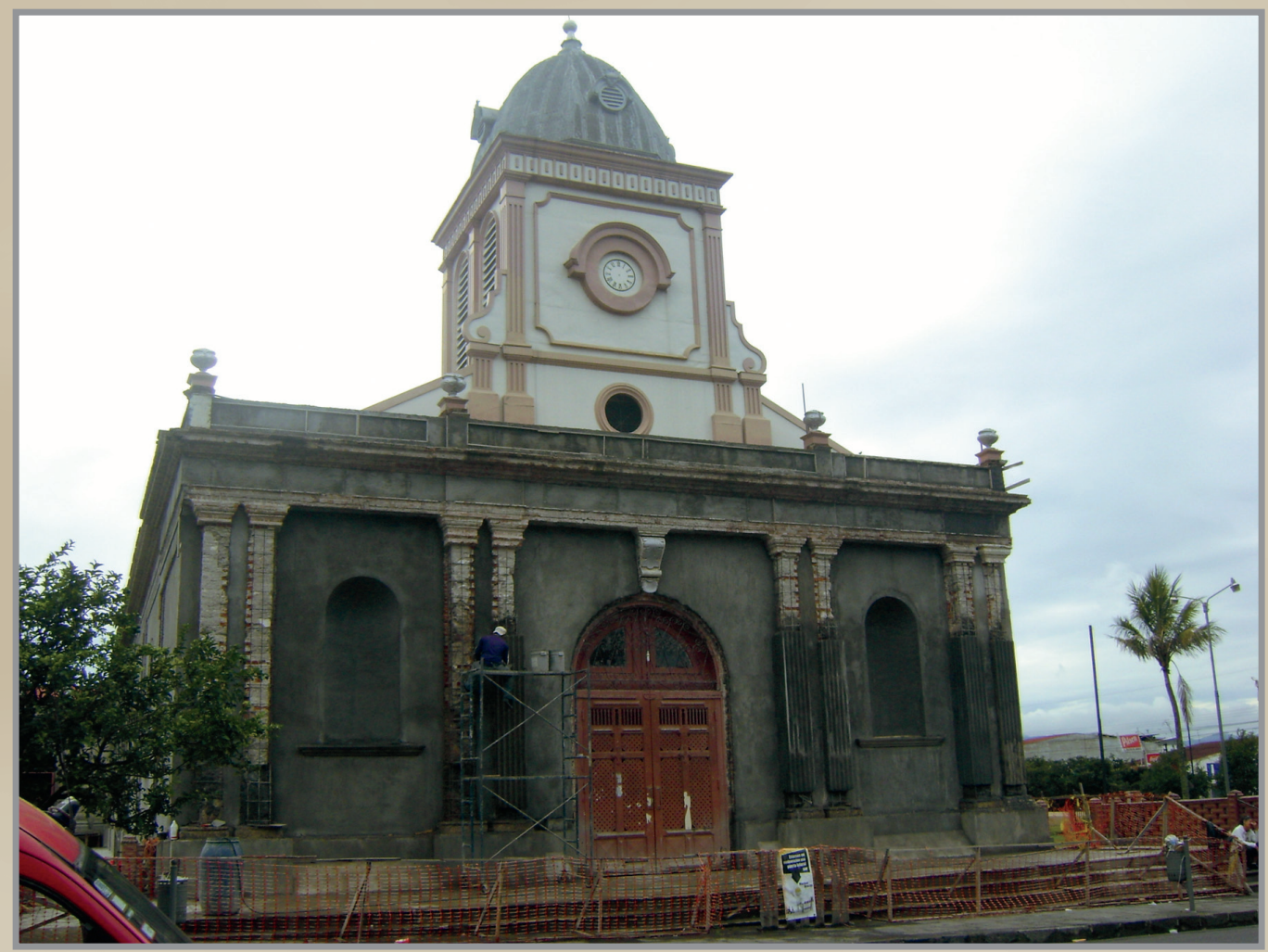

Fotografía 22.

Reconstrucción de la

fachada - 2010

Fuente: Rivas Vargas y Asociados S. A.

"Archivo fotográfico"

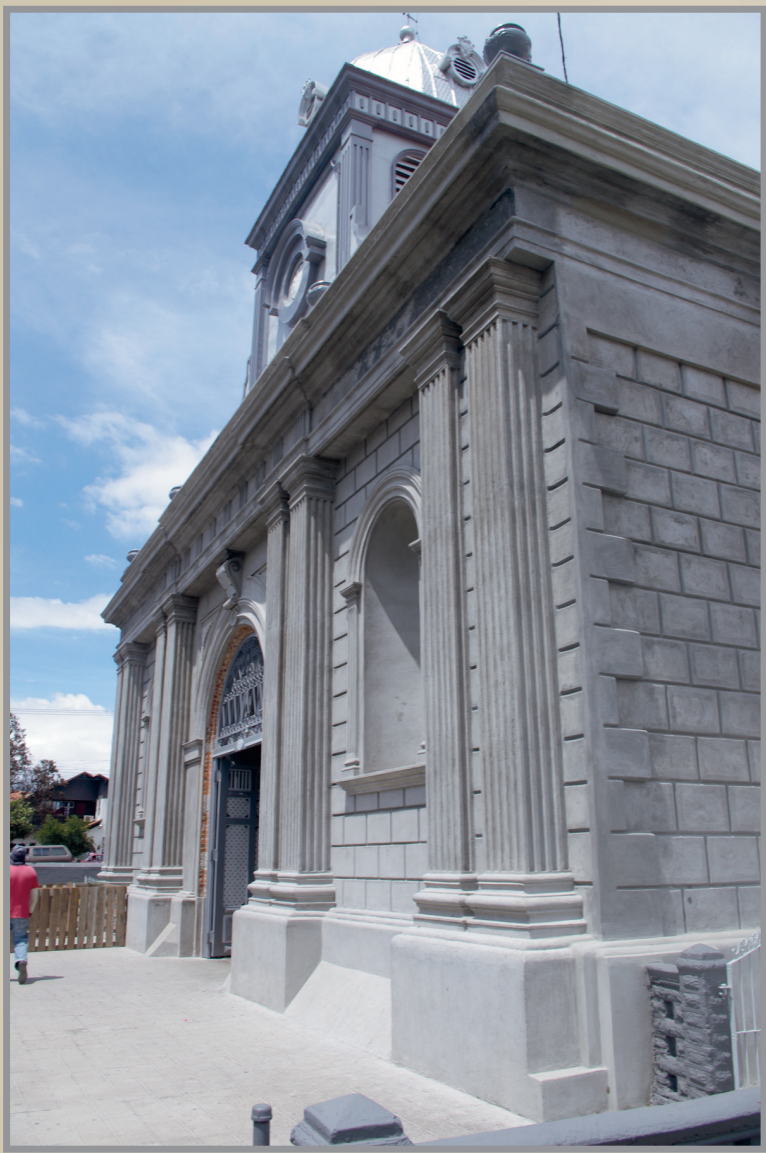

Fotografía 23 Reconstrucción de la fachada - 2012.

Fuente: Rivas Vargas y Asociados S. A. "Archivo fotográfico" 


\section{Conclusiones}

La evolución y el desarrollo eclesiástico que, en el siglo XIX, enfrentaron los sanjuaneños y que culmina con la creación de la parroquia en 1865, incidió en el proceso de formación de la identidad de San Juan. Esto posibilitó enfrentar la tragedia del incendio del templo parroquial a finales del siglo XIX.

Más que un simple hecho material, la reconstrucción valió para demostrar el coraje y la valentía del pueblo de San Juan, así como su fraternidad, voluntad y solidaridad. También sirvió para demostrar la colaboración y la generosa amistad de pueblos vecinos.

De igual manera, la reedificación nutrió y reprodujo la sociabilidad, la cotidianidad, las estructuras comunales y la identidad popular sanjuaneñas, a la vez que fomentó valores que siguen siendo muy necesarios. En especial, los turnos simbolizaron un punto medular de alianza social y un bastión de la convivencia y de la identidad local.

En definitiva, la reconstrucción del templo fortaleció y recreó el sentir de la identidad sanjuaneña, al aglutinar al pueblo en favor de una causa común, al identificarlos en torno a un objetivo de lucha comunal y al hacerlos comprender que unidos podían resolver los grandes problemas que los aquejaban. La reedificación repercutió de tal forma que, posteriormente, los sanjuaneños iniciaron la lucha por tener una cañería y el cantonato a partir de 1914.

La última restauración del templo parroquial de San Juan Bautista inició en 2009. Esta ha representado una obra de gran envergadura, pues dicho proceso ha estado enfocado en restaurar y conservar fielmente todos los detalles del templo, para mantener el lenguaje arquitectónico. Así, este proceso restaurativo no solamente implica un asunto de orden económico, sino también cultural, histórico y patrimonial y, por supuesto, arquitectónico y comunal. Al momento de escribir estas líneas (noviembre de 2013) la restauración continúa en sus últimos detalles.

A finales del siglo XIX, los sanjuaneños reconstruyeron su templo, por lo que es evidente que los infortunios y las desventuras no desaniman, sino antes alientan y comprometen a redoblar esfuerzos. Que la experiencia de hace más de un siglo sirva de aliento y apoyo a los sanjuaneños que hoy restauran su templo parroquial.

\section{Notas}

1. ANCR, C, 1767, 1834, f. 1.

2. ANCR, $M, 530,1834$, f. 19

3. Otras ermitas construidas posteriormente en la zona de El Murciélago estuvieron en San Vicente en 1840. En Goicoechea, el 9 de octubre de 1844, fue concedido, a los vecinos del entonces cuartel de San José del barrio de Los Santos, el permiso para construir la primera ermita en honor a su santo patrono, San José. En cuanto a San Isidro de Coronado, no está claro el origen religioso; sin embargo, es evidente que entre 1864 y 1867 ya existía un oratorio. En 1862 se obtuvo el permiso para construir la "iglesia vieja" y la misma se concluyó y se bendijo el 21 de noviembre de 1880. (Campos, 2001, pp. 227-232).

4. ANCR, C, 4657, 1838, f. 2. (González, 1906, p. 12). 
5. ANCR, PCSJ, 516, 1838, fs. 44-48v.

6. ACM, FA-DE, 87,1852 , fs. 123,123 v.

7. ACM, FA-DE, 145, 1864, fs. 221, 221 v.

8- $\quad$ ACM, FA-DE, 145, 1864, fs. 222v, 223, 223v, 229v, 230, 230v, 231, 231v.

9. El Presbítero Víctor de Gréve, junto con el cura Antonio Monestel, publican para 1897, en unión de otros sacerdotes, el periódico de la Diócesis de Costa Rica: El Mensajero del Clero.

10. "El Incendio de la Iglesia de San Juan. Datos Precisos", Diario de Costa Rica (San José), 28 de setiembre de 1897, s.p.; "San Juan se Retuerce Todavía", El Heraldo de Costa Rica (San José), 29 de setiembre de 1897, s.p. y "El Incendio de la Iglesia de San Juan", El Mensajero del Clero (San José), 31 de octubre de 1897, pp. 169-170.

11. "Lo de San Juan", La República (San José), 28 de setiembre de 1897, s. p. y ANCR, Juzgado del Crimen - San José, 4575, 1897, f. 4v. Según este último documento y por diligencia de la Alcaldía Primera de San José, se nombraron como peritos para valorar las pérdidas en la Iglesia de San Juan tras el incendio, a los señores: Máximo Morales (artesano) y a Manuel Valerín Requenes (escribiente).

12. ANCR, P, 1544,1897 , s. f.

13. "Incendio", La Prensa Libre (San José), 28 de setiembre de 1897, s.p.; "Incendio", EI Heraldo de Costa Rica (San José), 28 de setiembre de 1897, s.p.; "Lo de San Juan", La República (San José), 28 de setiembre de 1897, s. p. y "San Juan se Retuerce Todavía", El Heraldo de Costa Rica (San José), 29 de setiembre de 1897, s.p.

14. ANCR, Juzgado del Crimen - San José, 4575, 1897, f. 3v.

15. Tibás un Cantón que le ha dado paso a la Industria, s. d.; Paz, 1993, 11.

16. ANCR, Juzgado del Crimen - San José, 4575,1897 , fs. 2v, 3 f y $3 v$.

17. "El Incendio de la Iglesia de San Juan", El Mensajero del Clero (San José), 31 de octubre de 1897, p. 170; "El Incendio de la Iglesia de San Juan. Datos Precisos", Diario de Costa Rica (San José), 28 de setiembre de 1897, s.p.; Diario de Costa Rica (San José), 29 y 30 de setiembre de 1897, s.p.; "Lo de San Juan", La República (San José), 28 de setiembre de 1897, s. p.; "Así se Hace", La Prensa Libre (San José), 29 de setiembre de 1897, s.p. e "Incendio", El Heraldo de Costa Rica (San José), 28 de setiembre de 1897, s.p.

18. ACM, LPA, LA No. 6, 1897, fs. 361, 362; ACM, FA-DE, 435, 1897, fs. 404, 472 y ACM, Actas, Parroquia de San Juan de Tibás, Junta Edificadora, caja 1, libro 1, fs. 57, 68, 122, 128, 134, 142, 160, 186, 188. (En adelante esta última fuente se citará así: ACM, Actas, fs.). Es probable que en el transcurso de la reedificación, otros sanjuaneños hayan integrado la Junta Edificadora y las fuentes consultadas no los mencionen o bien no indiquen el momento preciso en que se incorporaron.

19. No fue posible hallar la fecha de su nombramiento. 
20. ACM, Actas, fs. 44, 49, 50, 68, 69, 70, 141, 160, 187.

21. ACM, Actas, f. 31.

22. ACM, Actas, f. 33. Es probable que el señor Baltasar Valenciano se haya incorporado a la Junta Edificadora en el trascurso del segundo semestre del año de 1897.

23. ACM, Actas, fs. $72,73$.

24. ACM, Actas, f. 105.

25. La fuente consultada no indicó el nombre de entidad bancaria que prestó el dinero. ACM, Actas, fs. 55, 71.

26. ACM, Actas, fs. $71,86,87,89,91,146$.

27. ACM, Actas, f. 148.

28. ACM, Actas, f. 84 .

29. ACM, Actas, fs. 89-90.

30. Aunque el término empleado por las fuentes es "rifa" y pese a que la explicación al respecto es muy limitada, es probable que se refiera al juego del bingo o lotería que se acostumbraba hacer con obsequios que la misma población aportaba.

31. ANCR, P, 1544, 1897, s. f.

32. La Gaceta (San José), 11 de diciembre de 1897, p. 616.

33. "Turno de San Juan", El Eco Católico de Costa Rica (San José), 29 de enero de 1898, p. 16.

34. Se revisaron diversos periódicos con la finalidad de hallar información relativa a los turnos por efectuarse probablemente en mayo y en agosto de 1898; sin embargo, no fue posible hallar dicha información. Entre los periódicos consultados están los siguientes: La Nueva Prensa (San José), días: 2, 4, 7, 9, 11, 14, 16, 17, 18 y 19 de agosto de 1898; El Heraldo (San José), días: 3 al 7 y 9 al 12 de agosto de 1898; Diario de Costa Rica (San José), días: 28 al 30 de enero de 1898 y 1, 2, 4, 5, 6, 8 al 13, 15 al 17 de febrero de 1898; El Anunciador Costarricense (San José), días: 16 de enero de 1898, 1 y 16 de febrero de 1898, 1 de marzo de 1898, 16 de abril de 1898, 1 y 16 de mayo de 1898, 1 de junio de 1898, 1 y 16 de agosto de 1898; Sancho Panza (San José), días: 29 de enero 1898 y 12 de febrero de 1898; El Fígaro (San José), días: 1, 2, 4 5, 6, 8, 9, 12 de febrero de 1898; El Pabellón Cubano (San José), días: 23 de enero de 1898 y 6 de febrero de 1898 El Heraldo de Costa Rica (San José), días: 20 de enero al 28 de febrero de 1898 y del 1 de mayo al 10 junio de 1898.

35. ACM, Actas, f. 60.

36. ACM, Actas, fs. 66,72 .

37. ACM, Actas, f. 75 . 
38. ACM, Actas, fs. 121, 127, 133.

39. ACM, Actas, fs. 139, 141. Ante la renuncia del comisionado del distrito Central, señor José Vega, se nombró a don Ramón Marín.

40. ANCR, F, 1448, 1897, s. f. Es importante destacar que a finales del Siglo XIX se encontraban en edificación otras estructuras como el Edificio Metálico y el techo de la Iglesia de Grecia, los cuales se construyeron también en metal. ANCR, C, 3333, 1895, pp VIII-IX.

41. Augusto Fla Chebba fue un destacado ingeniero que laboró para la Sección de Construcciones de la Dirección General de Obras Públicas; además, llegó a desempañarse como el jefe de dicha Sección. Por lo anterior, inspeccionó y diseñó una gran cantidad de obras. Secretaría de Fomento, 1896: 3-4, 32.

42. ACM, Actas, f. 31.

43. Dicho reglamento establecía lo siguiente: "A)-Exitar [sic] el solícito cuidado del señor maestro de capilla. B)-Fuera de éste nadie tocará el instrumento sin permiso de la Junta. C)-Ningún miembro de la Junta dará por sí solo este permiso. D)-No le es permitido al señor maestro ceder el armónium a otro. E)-Se encarga a los señores cura y mayordomo dar el permiso en casos extraordinarios como por ejemplo en grandes solemnidades". ACM, Actas, fs. 32, 33.

44. ACM, Actas, f. 41 .

45. ACM, Actas, f. 40.

46. ACM, Actas, fs. 55, 77, 143.

47. Según las fuentes consultadas, algunos elementos necesarios para la reedificación de la Iglesia, fueron importados de París; no obstante, dichas fuentes no indican claramente lo que se trajo de Francia. ACM, Actas, fs. 62, 65.

48. ACM, Actas, f. 44.

49. ACM, Actas, f. 46 .

50. ACM, Actas, f. 45 .

51. ACM, Actas, f. 49.

52. ACM, Actas, f. 52 .

53. ACM, Actas, f. 56 .

54. ACM, Actas, f. 52.

55. ANCR, H, 40742, 1898, s.f.

56. ANCR, H, 28799, 1899, s. f. 
57. ACM, Actas, f. 61

58. ACM, Actas, fs. 101, 103, 104-106, 113-114, 117-118, 125, 127-129, 132, 137.

59. ACM, Actas, f. 130.

60. Entrevista realizada por Jafeth Campos Ramírez al señor Fabio Rojas Rodríguez, San Juan de Tibás, 11 de enero de 2011; Jiménez, 1947: 59.

61. ACM, Actas, f. 74.

62. ACM, Actas, f. 169.

63. ACM, Actas, f. 169.

64. ACM, Actas, f. 52, 66, 71, 78

65. ACM, Actas, f. 179.

66. ACM, Actas, fs. 181, 183.

67. ANCR, Juzgado Primero Civil -San José, 2226, 1900, s. f.

68. También llama la atención que el 22 de mayo de 1903, el señor Gastón Castex y la Junta Edificadora de la iglesia de San Rafael de Heredia, celebraron contrato para que el primero colocara ventanas (ojivales y redondas) y linternillas en dicha iglesia y la sacristía. Sin embargo, la obra nunca se realizó. Por ello, el señor Castex Marcaillon fue demandado y al final se rescindió el contrato, se le condenó al pago de los daños y perjuicios (por falta de cumplimiento) y de las costas procesales y personales del juicio. ANCR, Juzgado Segundo Civil - San José, 8589, 1903-1908, s. f.

69. Entrevista realizada por Jafeth Campos Ramírez a los arquitectos Mario Rivas Vargas, Mario Rivas Ramírez y Elena Campos Borrás, Moravia, 10 de mayo de 2012.

70. Entrevista realizada por Jafeth Campos Ramírez a los arquitectos Mario Rivas Vargas, Mario Rivas Ramírez y Elena Campos Borrás. Moravia, 19 de noviembre de 2013.

71. Según los arquitectos Mario Rivas Vargas y Mario Rivas Ramírez, el cielo raso (forros metálicos) se encuentra deteriorado, incluso pareciera presentar corrosión y consecuentemente agujeros y grietas (producto de filtraciones y humedad). Sin embargo, esta reparación no se contempla, por el momento, dentro de la restauración actual; además, por sus características (cielo raso en metal y decorado con diferentes diseños e ilustraciones) requiere la participación de un técnico especializado. (Entrevista realizada por Jafeth Campos Ramírez a los arquitectos Mario Rivas Vargas, Mario Rivas Ramírez y Elena Campos Borrás, San Juan, 20 de noviembre de 2013 y visita de campo al templo parroquial de San Juan de Tibás, 20 de noviembre de 2013).

72. Ministerio de Cultura y Juventud, Centro de Investigación y Conservación del Patrimonio Cultural, Archivo de Bienes Inmuebles Patrimoniales, Expediente histórico Basílica de San Juan (Tibás - San José).

73. Entrevista realizada por Jafeth Campos Ramírez a los arquitectos Mario Rivas Vargas, Mario Rivas Ramírez y Elena Campos Borrás, Moravia, 19 de noviembre de 2013. 


\section{Fuentes primarias}

A. Inéditas

1. Archivo Nacional de Costa Rica (ANCR)

-Fondo - Congreso (C): 1767, 3333, 4657.

-Fondo - Fomento (F): 1448.

-Fondo - Fotografía (Ft): 7183.

-Fondo - Hacienda (H): 40742, 28799.

-Fondo - Juzgado del Crimen - San José: 4575.

-Fondo - Juzgado Primero Civil - San José: 2226.

-Fondo - Juzgado Segundo Civil - San José: 8589.

-Fondo - Mapas y Planos (MyP): 317, 318.

-Fondo - Municipal (M): 530.

-Fondo - Policía (P): 1544.

-Fondo - Protocolo Colonial de San José (PCSJ): 516.

\section{Archivo de la Curia Metropolitana (ACM)}

-Sección: Actas - Parroquia de San Juan de Tibás - Junta Edificadora, caja 1, libro 1. -Sección: Fondos Antiguos - Documentación Encuadernada (FA-DE), caja 87, 145, 435. -Sección: Libros Pastorales y Administrativos (LPA), Serie: Libros de Acuerdos (LA), No. 6.

\section{Archivos Fotográficos Privados}

-Benavides Barquero, Manuel.

- Campos Ramírez, Jafeth.

-Parroquia San Juan Bautista, San Juan de Tibás.

-Rivas Vargas y Asociados S. A.

\section{Ministerio de Cultura y Juventud, Centro de Investigación y Conservación del Patrimonio Cultural, Archivo de Bienes Inmuebles Patrimoniales}

Expediente histórico Basílica de San Juan (Tibás - San José).

\section{B. Orales}

Rivas Vargas, Mario A.; Rivas Ramírez, Mario A. y Campos Borrás, Elena. (10 de mayo de 2012, 23 de noviembre de 2012, 19, 20 y 23 de noviembre de 2013). Moravia.

Rojas Rodríguez, Fabio. (11 de enero de 2011). San Juan de Tibás.

\section{Visita de campo}

Templo Parroquial de San Juan de Tibás, 20 de noviembre de 2013. 


\section{Bibliografía}

Andrade C., María de la Paz et al. (1993). Diagnóstico Situacional de Salud, EBAIS E1. Tibás: Clínica Integrada de Tibás (COOPESAín R.L).

Campos Ramírez, Jafeth. (2001). San Juan de El Murciélago, Cantón de Tibás: una Interpretación Histórica con Perspectiva Geográfica (1914-1994). Tesis de licenciatura en Historia, Facultad de Ciencias Sociales: Universidad de Costa Rica.

Costa Rica, Secretaría de Fomento. (1896). Memoria de Fomento 1896. San José: Tipografía Nacional.

González Víquez, Cleto. (1906). Límites entre San Juan y San Vicente. San José: Tipografía Nacional.

Jiménez Rodríguez, Luz Marina. (1947). Monografía de Tibás. Tesis de graduación, Escuela de Pedagogía: Universidad de Costa Rica.

Rivas Vargas y Asociados S. A. (2009). "Informe Técnico acerca de las Condiciones Constructivas de los Repellos del Templo de la Parroquia San Juan Bautista de Tibás".

(s. d.). Tibás un Cantón que le ha dado paso a la Industria. Mimeografiado.

\section{Periódicos}

-Diario de Costa Rica (San José)

"El Incendio de la Iglesia de San Juan. Datos Precisos", 28 de setiembre de 1897; 29 y 30 de setiembre de 1897.

-El Eco Católico de Costa Rica (San José)

"Turno de San Juan", 29 de enero de 1898; 12 de febrero de 1898; "El Pueblo de San Juan", 27 de agosto de 1898; 4 de febrero de 1899.

-El Heraldo de Costa Rica (San José)

"Incendio", 28 de setiembre de 1897; "San Juan se Retuerce Todavía", 29 de setiembre de 1897.

-El Mensajero del Clero (San José)

"El Incendio de la Iglesia de San Juan", 31 de octubre de 1897; "San Juan", 31 de agosto de 1898; "San Juan", 30 de septiembre de 1898.

-La Gaceta (San José): 11 de diciembre de 1897.

-La Prensa Libre (San José)

"Incendio", 28 de setiembre de 1897; "Así se Hace", 29 de setiembre de 1897.

-La República (San José)

"Lo de San Juan", 28 de setiembre de 1897.

-La Tribuna (San José)

"Tibás, Tierra Feliz del Amor y la Alegría", 14 de octubre 1934. 
